\title{
African Asylum Seekers in Europe: The Interplay between Foreign Aid and Governance in Origin Countries
}

\author{
Jordi Ripollés ${ }^{1}$ Inmaculada Martínez-Zarzoso ${ }^{1,2}$ iD
}

Accepted: 30 November 2021 / Published online: 28 December 2021

(C) The Author(s) 2021

\begin{abstract}
This paper empirically investigates the effects of governance quality on the number of African asylum seekers in Europe over the period 1996-2018 and evaluates the extent to which official development aid acts as a catalyst. With this purpose in mind, different gravity model specifications and estimation approaches have been employed. The obtained results suggest that the asylum flows are strongly determined by governance quality in the country of origin and that this effect does depend on the amount of foreign aid received from developed countries. Moreover, it is also found that development aid is only effective in reducing asylum applications coming from countries with good governance. Moreover, we find no differences in the estimated elasticity of foreign aid on asylum claims for the beneficiaries of the European Union Emergency Trust Fund (EUTF) for Africa, the main aim of which has been to improve living conditions of potential migrants in their countries of origin.
\end{abstract}

Keywords Asylum seekers · ODA · Africa · European Union · Governance · Gravity model

JEL F35 $\cdot 011 \cdot 019$

\section{Introduction}

Over the last decades, the continent of Africa has been plagued by political conflicts and frequent outbursts of violence. Examples include the Rwandan genocide in 1994 and the wave of revolutions known as the Arab Spring that unsettled North Africa in 2010. Africa is also a continent where autocratic regimes persist: out of the 51

Inmaculada Martínez-Zarzoso

imartin@gwdg.de

1 Department of Economics and Institute of International Economics, University, Jaume I Av. De Vicent Sos Baynat, s/n, 12071 Castelló, Spain

2 Department of Economics, University of Göttingen, Platz der Goettinger Sieben 3, 37073 Goettingen, Germany 
African countries, 7 are still ruled by presidents that came to power before $1990 .^{1}$ On the other side of the Mediterranean, Europe emerges as a politically stable and highly developed region geographically close to North Africa. It is not surprising that the European Union (EU) -known for its stability and security- is a popular migration destination for people from less privileged African countries in search of a better life.

Migrants from politically unstable countries usually become asylum seekers and attempt to obtain the status of refugee in the receiving country. Given the remarkable increase in these flows, especially after the open-door policy announced by the German government in 2015, one of main the EU goals concerning migration is to address the root causes of forced displacement. Hence, it is crucial to study and quantify the impact of specific push factors in the origin countries and the extent to which these push factors are mitigated by the arrival of foreign aid. This became an even more critical issue after the EU started to implement migration containment policies to control its southern borders and prevent the mass arrival of migrants to its territories.

The existing literature on the determinants of asylum migration has mainly focused on evaluating the role of political instability and conflict in the origin countries as push factors (Hatton 2016; Giménez-Gómez 2019, Kang 2021). A few studies have devoted special attention to development aid (Dreher et al. 2019; Murat 2020), but none have explored the interplay between governance and development aid and its relationship with migration in search of asylum.

The purpose of this paper is to investigate the impact of governance quality and official development aid (ODA), and the interplay between them, on the flows of asylum seekers from African to European countries. Additionally, we evaluate the effectiveness of the European Union Emergency Trust Fund (EUTF) for Africa, ${ }^{2}$ which is a central part of the EU's migration policy in Africa (Castillejo 2017).

The main novelty of our work with respect to the existing literature is that it focuses on governance as a determinant of asylum seeking from the African continent to Europe, incorporating development aid as moderating factor. To our knowledge, none of the recent papers highlighting the role of governance in explaining asylum migration have considered development aid as a potential limiting factor. Regarding methodology, we apply a gravity model to annual bilateral migration flows between 51 African origin countries and 24 European destination countries over the period from 1996 to 2018 . We control for unobserved country heterogeneity using a fixed effects model that assesses the responsiveness of emigration to timevarying origin country characteristics. We tackle endogeneity issues by applying

\footnotetext{
1 One of the most prominent examples is Robert Mugabe, the long-standing president of Zimbabwe, with a long track record of exploiting the country's resources, liaising with corrupt elites and living in luxury, while the majority of the country's population lives in extreme poverty.

2 The EUTF was launched in November 2015 and signed by 25 EU countries, Norway and Switzerland. Its main aim is to support stability, security and resilience in African countries to tackle the causes of irregular migration and forced displacement in origin. A total of 4.7 billion Euros have been invested in programs to improve governance and conflict prevention and create employment opportunities. https://ec. europa.eu/trustfundforafrica/.
} 
instrumental variables methods using external and internal instruments proposed in the related literature. We hypothesize that the driving forces of emigration have their roots in specific limitations of the countries of origin. If a country cannot provide its citizens with sufficient security or social and economic opportunities, the expectations of certain parts of the population are not met, which is likely to fuel emigration. In order to properly identify the effect, we control for destination country features that also influence forced migration, such as migration policies or wellbeing, by adding destination-year fixed effects to the specification. This set of fixed effects is a proxy for all factors that are destination-specific and vary over time, which allows us to focus exclusively on the country of origin's determinants of migration.

Our findings suggest that asylum seekers depend inversely on the governance quality in the origin country, especially when foreign aid is received. Additionally, we find that foreign aid contributes to reducing the number of African asylum applications in Europe only when the level of governance quality in the origin country is relatively high. However, the opposite is the case for lower levels of governance. The results are robust to several changes in the model specification and two different instrumentation strategies. Moreover, the empirical results indicate that the estimated effect of ODA on asylum claims does not differ between EUTF beneficiaries ${ }^{3}$ and other African countries. At the same time, it is important to highlight that the effects could materialize in the medium to long term, meaning further evaluations would be needed once more data become available for a longer time span.

The rest of the paper is organized as follows. Section 2 presents a review of the related literature on migration flows and its determinants, with specific references to asylum migration. Section 3 presents the model specification, estimation strategies and data sources, while Sect. 4 describes the main results and includes some robustness checks. Finally, Sect. 5 provides the conclusions and policy implications.

\section{Literature Review}

In this section, we review the related theoretical and empirical literature on the determinants of migration. Although many studies have explored such factors in relation to destination countries, our primary focus is on a growing strand of research that emphasizes country-of-origin determinants.

Most approaches that study the determinants of migration model individuals' decision whether to leave or stay in their country of origin. A variety of factors involving economic, socio-demographic and political aspects in the origin and the destination countries influence this decision. In the country of origin, a potential migrant is faced with "push" factors that increase his/her incentives to leave or "stay" factors that have the opposite effect. In the destination country, positive

\footnotetext{
3 List of beneficiaries in three regions: 1) North Africa: Morocco, Algeria, Tunisia, Libya and Egypt. 2) The Sahel and Lake Chad: Burkina Faso, Cameroon, Chad, Côte d'Ivoire, the Gambia, Ghana, Guinea, Mali, Mauritania, Niger, Nigeria and Senegal. 3) Horn of Africa: Djibouti, Eritrea, Ethiopia, Kenya, Somalia, South Sudan, Sudan, Tanzania and Uganda.
} 
"pull" factors attract the potential migrant as opposed to negative "stay away" factors (Bodvarsson and Van den Berg 2013). Apart from these factors, the migration decision is influenced by the costs involved in the movement, such as transportation, loss of earnings, visa regulations or migration quotas. Lee (1966) identified potential push and pull factors and summarized them in what is now commonly referred to as the push and pull model. ${ }^{4}$

Potential economic push factors in the country of origin are high unemployment, a lack of opportunities and the prevalence of poverty and starvation. According to the neoclassical migration theory, the most important push factor is the per capita income difference between origin and destination countries. It has been argued that an increasing GDP in the country of origin, all other things being equal, would result in lower migrant outflows (see Roy 1951 and Borjas 1989). While the majority of empirical studies find support for this theoretical prediction (e.g., Karras and Chiswick 1999; Hatton and Williamson 2005; Neumayer 2005), other research do not. For instance, Lucas (2006) finds that richer African countries present higher emigration rates to the OECD. ${ }^{5}$ The author identifies several reasons why this phenomenon occurs, including structural labor market reform accompanying economic development, the reduction of international migration costs associated with improvements in income and education and migration pressure associated with population growth.

In addition to purely economic determinants, demographic development plays a role. Most African countries are still undergoing a demographic transition where rising incomes reduce child mortality, leading to higher population growth, which results in pressure on the labor market and eventually leads to increasing emigration. This reasoning is associated with the so-called 'migration transition theory'. For instance, whereas as a large share of elderly people could imply a higher financial burden on the economy, a large share of children will imply a large share of young adults and working population in the future (Azeng and Yogo, 2013). These higher share of young adults generates an increase in the labor supply, which when not coupled with an increase in labor demand generates potential emigrants. According to Mayda (2010), inequality among the population and general demographic pressure due to scarcity of land and overpopulation are expected to increase the emigration rate.

There are also ecological push factors such as natural, climate and environmental catastrophes; and potential shortages of resources like soil erosion and overfishing. Environmental degradation leads first of all to internal displacement, mostly to urban areas, which in extreme cases is then followed by international migration. That is, increasing labor supply in cities results in high urban unemployment that could increase migration to other countries (see Marchiori et al.

\footnotetext{
${ }^{4}$ Socio-economic pull factors are related to the availability of jobs, tolerance, functioning health and education systems, access to living quarters and to a broad range of cultural and leisure time facilities. Among the political factors are liberal immigration laws, possibilities for family reunification and a functioning legal system.

5 The phenomenon is consistent with the so-called "migration hump" introduced by Martin (1993) and Martin and Taylor (1996), which implies that emigration pressure temporarily increases with socio-economic development in poor countries, while it declines with development in richer countries.
} 
2012). The channels through which environmental changes accelerate emigration are summarized by Beine et al. (2015), who add a volatility channel, according to which risk-averse people want more security and therefore opt for migration.

Besides economic, demographic, and ecological push factors, part of the recent literature focuses on specific aspects of good governance. Political instability and conflict have a major effect on the size and composition of the migration flow (Raleigh 2011; Karemera et al. 2000; Docquier et al. 2007; Naudé 2010; Ziesemer 2011; Adepoju 2007). Karemera et al. (2000) were among the first to include political variables into a gravity model of migration when examining immigration flows to North America. They find that migration is positively related to restricted individual freedom, political rights and political instability in the source country. Many countries suffer from the fact that it is mainly high-skilled individuals that leave the country -the so-called 'brain drain'-. Docquier et al. (2007) find that brain drain increases with political instability, whereas government effectiveness has no significant influence on the composition of the migrant flow. Common ways of measuring political instability and conflict are the number of deaths in civil war (Dimant et al. 2013), number of regime changes (Dreher et al. 2011), irregular transfers of power (Karemera et al. 2000) and number of years in conflict (Naudé 2010). Naudé (2010) investigates the determinants of African migration and finds that armed conflict and lack of job opportunities are the main drivers of migration, whereas Rayp and Ruyssen (2010) investigate whether intra-regional migration in Africa is influenced not only by the level of democracy, but also by the number of years in conflict. Interestingly, they do not find any significant effect of these variables on intra-African migration. Differently, Czaika and de Haas (2011) identify the violation of human rights as an important driver of forced emigration by showing that emigration rates are especially high in countries that are seen as failed or fragile states. The authors conclude that the migration of high-skilled individuals is more likely as they try to improve their living and working conditions abroad. When looking in particular at forced migration, comparative studies have found that there are clear differences in the magnitude of movements caused by civil wars, international wars, genocides, politicides, and human rights violations (Davenport et al. 2003; Melander and Öberg 2006; Moore and Shellman 2004; Schmeidl 1997). Civil war is found to have the largest impact on migration, followed by genocide, whereas structural policy changes in a polity have lesser effects (Moore and Shellman 2004; Davenport et al. 2003).

Corruption is another push factor influencing individuals' migration decision. Dimant et al. (2013) find that corruption mostly fuels skilled emigration, because it worsens individuals' living and working conditions and lowers the returns to education. Corruption can lead to higher inequality in access to positions in the public administration and management structure of companies, given that it depends on networking and political connections. The association between corruption and migration is also empirically confirmed by Poprawe (2015) and Cooray and Schneider (2016). Other authors focus on democracy and political rights. For example, Hatton and Williamson (2011) analyze the emigration pressure of 62 
countries between 1970-2004, finding that civil rights have a significant impact on the migration decision, whereas the political regime is not found to affect the emigration rate. Rayp and Ruyssen (2010) look at intra-regional migration in Africa finding that, in line with Hatton and Williamson (2011), democracy and the political regime turn out not to be significant. However, Dreher et al. (2011), find that the level of democracy has a significant influence on migration.

In the last two decades, there are an increasing number of authors that compare the determinants of migration flows with those of asylum seekers, or that focus exclusively on the latter (Davenport et al. 2003; Hatton, 2011, 2016; Hatton and Moloney, 2015; Kang 2021; Moore and Shellman 2004; Murat 2020; Neumayer 2005, among others). Most of them find that political and institutional factors play a strong role in explaining these flows. Conversely, among the economic determinants, income in the origin country tends to reduce asylum claims. For instance, Hatton (2016) investigates the determinants of asylum seeker flows from 48 origin countries to 19 OECD destinations over the period 1997 to 2012 using a gravity model estimated with PPML. The author selects dyads (origin-destination pairs of countries) for which there were at least 300 applications over the period under study. His results indicate that political terror has one of the strongest effects among the factors at origin, and lack of civil liberties also shows a positive effect. However, lack of political rights does not have a positive effect, and nor does civil war deaths. The regressions run to analyze country-of-origin factors include destination-and-time dummies to control for all the asylum policies that vary by destination and time. Similarly, Kang (2021) investigates the determinants of asylum seeking, in this case for a sample of 7 EU receiving countries and 145 origin countries over the period 2008 to 2014 . The seven countries considered received more than $70 \%$ of the total asylum applications to EU members. He estimates a gravity model with PPML, using the number of applicants by origin country as the dependent variable. After controlling for destination-country fixed effects, his results show that greater political stability in the origin country significantly reduces emigration rates. Focusing on Africa, Giménez-Gómez et al. (2019) explore the determinants of migration and asylum-seekers migrating to Europe over the period 1990 to 2014. The methodology is similar to that used by Hatton (2016), with the main difference being that the dependent variables are not divided by the population of the country of origin, as Kang (2021) does. The results indicate that democracy, autocracy and civil liberty are significant factors explaining both migration and asylum flows.

Finally, another related strand of the literature has recently emerged, concerned with examining how migration and/or asylum flows could be affected by development aid (Dreher et al. 2019; Murat 2020; Neumayer 2005; Thielemann 2004). Unfortunately, the reported results are rather mixed. For instance, some authors find that aid positively affects economic development in receiving countries, which in turn could negatively affect outflows in the long run (Dreher et al. 2019; Lanati and Thiele 2018). In contrast, Berthélemy et al. (2009) show that aid could increase the ability of individuals to migrate by providing them with the financial means to do so or greater information on the donor country. Additionally, Murat (2020) exploits a dataset of 13 donor countries and 113 recipient countries for the period 1993-2013 and finds a U-shaped relationship between asylum seekers and foreign aid with respect to the level of economic development of origin countries. 
Table 5 in Appendix A provides a summary of the main empirical studies on migration and asylum seekers that include governance quality and development aid as determinants.

\section{Empirical Analysis}

The main framework for the empirical analysis is based on the gravity model that has been extensively used to investigate the determinants of bilateral flows of trade (e.g., Bergstrand 1985; Head and Mayer 2014; Feenstra 2016), migration (Ravenstein 1889; Beine et al. 2015; Bertoli and Fernández-Huertas 2017; among others), and more recently, asylum flows (Hatton 2016; Giménez-Gomez et al. 2019; Kang 2021). The model allows us to take advantage of the advances made in the trade and migration literature concerning the econometric estimation and isolation of the causal effect of specific economic and political factors as drivers of the flows (Bertoli and FernándezHuertas 2017; Mayda 2010). Below, we present the model specification, estimation strategy, data and results.

\subsection{Model Specification and Estimation strategy}

In line with the migration literature in economics, in order to study the determinants of asylum seeking we borrow the model from the theory explaining international migration, without distinguishing between forced and non-forced migration. According to this theory, which draws on random utility maximization theories (e.g., Borjas 1987, 1999; Beine et al. 2015; Ortega and Peri 2013), expected earnings differentials and other political and sociocultural factors could influence the individual's decision to migrate. Relying on the generalized gravity model formulation in Anderson (2011), bilateral migration can be expressed as follows,

$$
A_{i j t}=\frac{Y_{i t} Y_{j t}}{Y_{t}^{W}}\left(\frac{\theta_{i j t}}{\Omega_{i t} \Pi_{j t}}\right)^{1-\sigma}
$$

where $\mathrm{A}_{i j t}$ is bilateral migration (in our case asylum applications) from country $i$ to country $j$ in year $t$, and $Y_{i t}, Y_{j t}$ and $Y_{t}^{W}$ represent, respectively, the labor supply in the sending country, the receiving country and the world in year $t$. In addition, the parameter $\theta_{i j t}$ denotes the bilateral migration costs, while $\Omega_{i t}$ and $\Pi_{j t}$, respectively, represent the outward and inward multilateral resistance factors, which are a function of the cost of migrating from a country to all countries in the world. The parameter $\sigma$ represents the elasticity of substitution between workers. Then, the empirical specification in log-linear form is given by:

$$
\ln A_{i j t}=\ln Y_{i t}+\ln Y_{j t}-\ln Y_{t}^{W}+(1-\sigma) \ln \theta_{i j t}-(1-\sigma) \ln \Omega_{i t}-(1-\sigma) \ln \Pi_{j t}+\mu_{i j t}
$$

where $\ln$ denotes natural logarithms and $\mu_{i j t}$ is an error term. For our empirical analysis, the labor supply is approximated by the GDP per capita, while the bilateral 
migration costs are assumed to be a linear function of time-invariant determinants, including distance, colonial ties, and common language. Additionally, the multilateral resistance terms are proxied by time-varying socio-economic control variables describing the sending country, and origin time-invariant and destination time-varying fixed effects. We then analyze the effects on asylum migration of governance quality and foreign aid in the sending country by re-formulating Eq. (2) as follows:

$$
\begin{aligned}
\ln A_{i j t} & =\gamma_{0}+\gamma_{1} \ln G_{i t}+\gamma_{2} \ln O D A_{i j t}+\gamma_{3} \ln G_{i t} \cdot \ln O D A_{i j t} \\
& +\alpha_{1} \ln Y_{i t}+\alpha_{2} \operatorname{lndist}_{i j}+\alpha_{3} \text { colony }_{i j}+\alpha_{4} \text { clang }_{i j} \\
& +\beta^{\prime} Z_{i t}+\theta_{i}+\delta_{j t}+u_{i j t}
\end{aligned}
$$

where $G_{i t}$ denotes country $i$ 's average level of governance quality at time $t$ according to the governance indicators produced by Kaufmann et al. (2016), while $O D A_{i j t}$ represents country i's ODA per capita received from donor country $j$ at time $t$. The interaction term of these two variables is included in the specification to evaluate the potential interdependence of their corresponding effects. Additionally, dist $t_{i j}$ is the distance from sending country $i$ to receiving country $j$, and colony $_{i j}$ and clang $_{i j}$ are dummy variables for past colonial ties and common language shared between countries $i$ and $j$. The vector $Z$ represents the time-varying control variables for the sending country, including the number of fatalities, the size of the young population, the percentage of the population living in urban areas, the agriculture value added, the employment rate, the average temperature, and the average precipitation. As noted above, the remaining resistance terms are controlled with a set of dummies $\theta_{i}$ and $\delta_{j t}{ }^{6}$ Lastly, $u_{i j t}$ is the idiosyncratic error term.

We first estimate the baseline model given by Eq. (3) using Ordinary Least Squares (OLS), including origin time-invariant and destination time-varying fixed effects (FE), in which all the regressors are considered as exogenous. However, previous studies acknowledge that refugee inflows in donor countries may put pressure on the government to allocate more aid to their country of origin (e.g., Lahiri et al. 2000; Berthélemy et al. 2009; Czaika and Mayer 2011; Belloc 2015; Bermeo and Leblang 2015; Dreher et al. 2019; Murat 2020). In this case, the potential reverse causality between asylum seeking and foreign aid could lead to endogeneity problems. In order to address this issue, we also estimate Eq. (3) using the Two-stage Least Squares (2SLS) estimator, including two sets of instrumental variables for foreign aid. On the one hand, following the procedure proposed by Dreher et al. (2019), we employ as an instrument the aggregation over all donor countries of the interaction between the recipient country's probability of receiving aid (proxied by the time-average of a dummy variable indicating whether the recipient country annually receives positive bilateral aid) and the donor-government fractionalization. This instrument, denoted as $\sum_{j} \bar{P}_{i j} * F r a c_{j t}$, combines a time-invariant endogenous factor

\footnotetext{
${ }^{6}$ Our econometric specification explicitly includes traditional push factors that, according to the literature, often prevent people from leaving their home (Hatton, 2016). In contrast, we use fixed effects to control for unobserved time-invariant heterogeneity of source countries (e.g., cultural and historical heritage) and pull factors for the destination countries, the effect of which is not of interest in this study.
} 
that varies across donor-recipient pairs with a donor time-varying factor, which is positively correlated with the general government spending and provides exogenous variation to the amount of aid disbursed, independently of the number of asylum seekers. ${ }^{7}$ On the other hand, exploiting the panel data structure (Reed 2015), we have also instrumented ODA by its own lagged values in levels. ${ }^{8}$

Two additional model specifications are considered in the robustness checks of the empirical application. First, the model is estimated with the variables in levels by OLS and 2SLS, as given by,

$$
\begin{aligned}
A_{i j t} & =\gamma_{0}+\gamma_{1} G_{i t}+\gamma_{2} O D A_{i j t}+\gamma_{3} G_{i t} \cdot O D A_{i j t} \\
& +\alpha_{1} Y_{i t}+\alpha_{2} \text { dist }_{i j}+\alpha_{3} \text { colony }_{i j}+\alpha_{4} \text { clang }_{i j} \\
& +\beta^{\prime} Z_{i t}+\theta_{i}+\delta_{j t}+u_{i j t}
\end{aligned}
$$

where all variables have already been described below Eq. (3).

In addition, the gravity model is also estimated using Poisson Pseudo-Maximum Likelihood (PPML), with the dependent variable in levels to account for the zeroes the bilateral asylum applications. Using the PPML estimator proposed by Santos Silva and Tenreyro (2006), and recommended by Yotov et al. (2016), we not only account for zero values of the dependent variable, but also for heteroskedasticity in the error term that is inherent to the log-linearization of the gravity model. In this last case, in addition to the PPML estimator, we also use the PPML with the previously considered instrumental variables (PPML-IV) via the control-function approach suggested by Wooldridge (2015). The corresponding model is given by,

$$
\begin{aligned}
A_{i j t} & =\exp \left(\gamma_{0}+\gamma_{1} \ln G_{i t}+\gamma_{2} \ln O D A_{i j t}+\gamma_{3} \ln G_{i t} \cdot \ln O D A_{i j t}\right. \\
& +\alpha_{1} \ln Y_{i t}+\alpha_{2} \operatorname{lndist}_{i j}+\alpha_{3} \text { colony }_{i j}+\alpha_{4} \text { clang }_{i j} \\
& \left.+\beta^{\prime} Z_{i t}+\theta_{i}+\delta_{j t}\right) u_{i j t}
\end{aligned}
$$

\subsection{Data Sources}

The empirical analysis uses annual data on 51 source countries in Africa and 24 destination countries in Europe (Table 6 in the Appendix B shows the list of countries covered) for the period 1996-2018. The dataset comes from different sources. First, bilateral data on the number of asylum seekers have been taken from the OECD International Migration Database, and information on the total bilateral ODA comes from the OECD Development Statistics. Second, the geographical distance and information regarding colonial ties and common language come from the Centre d'Etudes Prospectives et d'Informations

\footnotetext{
7 The data corresponding to the donor-government fractionalization have been obtained from the Polity IV Project (Center for Systemic Peace, 2017).

8 Our findings are robust to the use of alternative instrumental variables. For instance, following Lewbel (1997) and Gamso and Yuldashev (2018), we have used as an alternative the second and third moments of the endogenous regressor, rather than using their own lagged values. The corresponding results are not reported here for reasons of space, but they are available from the authors on request.
} 
Table 1 Summary statistics

\begin{tabular}{llllll}
\hline Variable & Observations & Average & Standard deviation & Min & Max \\
\hline$A_{i j t}$ & 22,614 & 92.182 & 533.901 & 0 & 26,698 \\
$G_{i t}$ & 28,152 & 31.260 & 18.485 & 1.182 & 77.480 \\
ODA $_{i j t}$ & 28,152 & 0.942 & 6.115 & -44.881 & 434.544 \\
$Y_{i t}$ & 27,696 & $2,369.668$ & 3,099 & 188 & 20,513 \\
dist $_{i j}$ & 28,152 & $5,827.290$ & 1,984 & 562 & 10,487 \\
colony $_{i j}$ & 28,152 & 0.044 & 0.205 & 0 & 1 \\
clang $_{i j}$ & 28,152 & 0.069 & 0.254 & 0 & 1 \\
fatal $_{i t}$ & 28,152 & 474.031 & 3,226 & 0 & 73,811 \\
ypop $_{j t}$ & 28,152 & $5,192,045$ & $7,346,791$ & 20,296 & $51,900,000$ \\
urb $_{i t}$ & 28,152 & 40.728 & 17.106 & 7.412 & 89.370 \\
agric $_{i t}$ & 26,688 & 22.097 & 14.413 & 0.893 & 79.042 \\
employr $_{i t}$ & 27,768 & 60.194 & 14.545 & 30.601 & 87.818 \\
temp $_{i t}$ & 28,152 & 24.481 & 3.195 & 12.628 & 29.541 \\
precip $_{i t}$ & 28,152 & 83.754 & 54.572 & 1.569 & 273.520 \\
\hline
\end{tabular}

Internationales (CEPII). Third, the number of fatalities has been sourced from the Armed Conflict Location and Event Data Project (ACLED), while the size of the young population (15-29 years) in the source country has been retrieved from the United Nations. Data on government fractionalization has been collected from the Database of Political Institutions (Cruz et al. 2018). Finally, the remaining socio-economic, environmental and institutional variables are from the World Bank. The original data sources and the correlation matrix of variables are presented in Tables 7 and 8, respectively, in the Appendix C. Summary statistics of the variables used in the empirical analysis are shown in Table 1.

\section{Main Results}

Table 2 displays the estimated results of the baseline model from Eq. (3) obtained using the above-mentioned estimators with heteroskedasticity- and autocorrelationconsistent standard errors. ${ }^{9}$ More specifically, columns 1 and 2 present the OLS estimation results considering, respectively, the specification without and with the interaction term between ODA and governance, ${ }^{10}$ while columns 3 and 4 report the 2SLS results of the analogous specifications when development aid is instrumented. The corresponding first-stage regressions results are shown in the Appendix (Table 9).

\footnotetext{
${ }^{9}$ Groupwise heteroskedasticity and serial correlation are present in our model as indicated by the Greene (2003) and Wooldridge (2010) tests for panel data.

10 Similarly, as in the recent literature (Chen, 2004; Dreher, et al. 2019), in our empirical analysis based on Eq. (3) we have included the natural logarithm of each continuous variable plus one in cases where the variable contains zero values. Additionally, since $O D A_{i j t}$ could take negative values, it has been transformed by using the function $\ln \left(O D A_{i j t}+1-\min \left(O D A_{i j t}\right)\right)$. In any case, results remain qualitatively similar if we just take the natural logarithm of each variable, losing observations.
} 
Table 2 Effect of governance quality and foreign aid on asylum migration (log-log model)

\begin{tabular}{|c|c|c|c|c|}
\hline \multirow[t]{2}{*}{ Dep. variable: $\ln A_{i j t}$} & \multicolumn{2}{|l|}{ FE } & \multicolumn{2}{|l|}{ IV-FE } \\
\hline & (1) & (2) & (3) & (4) \\
\hline $\ln G_{i t}$ & $\begin{array}{l}-0.733^{* * *} \\
(0.059)\end{array}$ & $\begin{array}{l}9.980^{* * * *} \\
(1.865)\end{array}$ & $\begin{array}{l}-0.764^{* * * *} \\
(0.063)\end{array}$ & $\begin{array}{c}21.816^{* * * *} \\
(3.987)\end{array}$ \\
\hline $\ln O D A_{i j t}$ & $\begin{array}{c}0.420^{*} \\
(0.244)\end{array}$ & $\begin{array}{l}10.129^{* * *} \\
(1.805)\end{array}$ & $\begin{array}{c}0.407 \\
(0.493)\end{array}$ & $\begin{array}{c}21.669^{* * *} \\
(3.772)\end{array}$ \\
\hline $\ln G_{i t} \cdot \ln O D A_{i j t}$ & & $\begin{array}{l}-2.785^{* * * *} \\
(0.485)\end{array}$ & & $\begin{array}{c}-5.872^{* * * *} \\
(1.038)\end{array}$ \\
\hline $\ln Y_{i t}$ & $\begin{array}{l}-0.305^{* *} \\
(0.129)\end{array}$ & $\begin{array}{l}-0.325^{* *} \\
(0.128)\end{array}$ & $\begin{array}{l}-0.323^{* *} \\
(0.146)\end{array}$ & $\begin{array}{l}-0.361^{* *} \\
(0.145)\end{array}$ \\
\hline lndist $_{i j}$ & $\begin{array}{l}-0.814^{* * *} \\
(0.184)\end{array}$ & $\begin{array}{l}-0.810^{* * * *} \\
(0.185)\end{array}$ & $\begin{array}{l}-0.784^{* * *} \\
(0.182)\end{array}$ & $\begin{array}{c}-0.761^{* * * *} \\
(0.181)\end{array}$ \\
\hline colony $_{i j}$ & $\begin{array}{c}0.867^{* * * *} \\
(0.164)\end{array}$ & $\begin{array}{l}0.805^{* * *} \\
(0.160)\end{array}$ & $\begin{array}{l}0.865^{* * * *} \\
(0.166)\end{array}$ & $\begin{array}{l}0.650^{* * *} \\
(0.162)\end{array}$ \\
\hline clang $_{i j}$ & $\begin{array}{l}1.033^{* * *} \\
(0.125)\end{array}$ & $\begin{array}{l}1.027^{* * * *} \\
(0.122)\end{array}$ & $\begin{array}{l}1.089^{* * *} \\
(0.123)\end{array}$ & $\begin{array}{l}1.057^{* * *} \\
(0.12)\end{array}$ \\
\hline $\operatorname{lnfatal}_{i t}$ & $\begin{array}{l}0.026^{* * *} \\
(0.008)\end{array}$ & $\begin{array}{l}0.027^{* * *} \\
(0.008)\end{array}$ & $\begin{array}{l}0.020^{* *} \\
(0.009)\end{array}$ & $\begin{array}{c}0.019^{* *} \\
(0.009)\end{array}$ \\
\hline lnypop $_{i t}$ & $\begin{array}{l}-1.168^{* * *} \\
(0.239)\end{array}$ & $\begin{array}{l}-1.130^{* * * *} \\
(0.236)\end{array}$ & $\begin{array}{l}-1.551^{\text {*** }} \\
(0.253)\end{array}$ & $\begin{array}{c}-1.461^{* * * *} \\
(0.249)\end{array}$ \\
\hline $\operatorname{lnurb}_{i t}$ & $\begin{array}{c}0.633^{*} \\
(0.332)\end{array}$ & $\begin{array}{c}0.537 \\
(0.327)\end{array}$ & $\begin{array}{c}0.818^{* *} \\
(0.394)\end{array}$ & $\begin{array}{c}0.613 \\
(0.384)\end{array}$ \\
\hline lnagric $_{i t}$ & $\begin{array}{c}0.066 \\
(0.075)\end{array}$ & $\begin{array}{c}0.065 \\
(0.074)\end{array}$ & $\begin{array}{c}-0.026 \\
(0.08)\end{array}$ & $\begin{array}{l}-0.025 \\
(0.08)\end{array}$ \\
\hline lnemployr $_{i t}$ & $\begin{array}{c}0.219 \\
(0.473)\end{array}$ & $\begin{array}{c}0.14 \\
(0.466)\end{array}$ & $\begin{array}{c}0.080 \\
(0.499)\end{array}$ & $\begin{array}{l}-0.022 \\
(0.495)\end{array}$ \\
\hline lntemp $_{i t}$ & $\begin{array}{c}1.709 \\
(1.192)\end{array}$ & $\begin{array}{r}1.737 \\
(1.18)\end{array}$ & $\begin{array}{l}2.894^{* * *} \\
(1.271)\end{array}$ & $\begin{array}{c}2.823^{* * *} \\
(1.246)\end{array}$ \\
\hline lnprecip $_{i t}$ & $\begin{array}{c}0.018 \\
(0.059)\end{array}$ & $\begin{array}{c}0.025 \\
(0.059)\end{array}$ & $\begin{array}{c}0.043 \\
(0.062)\end{array}$ & $\begin{array}{c}0.054 \\
(0.062)\end{array}$ \\
\hline Hansen $\mathrm{J}$ test & & & $\begin{array}{c}1.305 \\
{[0.861]}\end{array}$ & $\begin{array}{c}8.497 \\
{[0.291]}\end{array}$ \\
\hline Kleibergen-Paap rk LM test & & & $\begin{array}{c}9.665 \\
{[0.085]}\end{array}$ & $\begin{array}{l}53.193 \\
{[0.000]}\end{array}$ \\
\hline Kleibergen-Paap rk Wald F & & & 15.576 & 10.427 \\
\hline Durbin-Wu-Hausman test & & & $\begin{array}{l}80.970 \\
{[0.000]}\end{array}$ & $\begin{array}{r}145.490 \\
{[0.000]}\end{array}$ \\
\hline $\mathrm{R}^{2}$ & 0.696 & 0.700 & & \\
\hline AIC & 65,413 & 65,163 & 58,202 & 58,226 \\
\hline Obs. (NxT) & 21,220 & 21,220 & 18,877 & 18,877 \\
\hline
\end{tabular}

All regressions include origin (i) and destination-year (jt) fixed effects. Sampled period ranges from 1996 to 2018. Heteroskedasticity- and autocorrelation-consistent s.e. are presented in parentheses, while p-values are in brackets. We use ${ }^{*},{ }^{* *}$, and ${ }^{* * *}$ to denote statistical significance at the $10 \%, 5 \%$, and $1 \%$ levels, respectively. The IV-FE refers to the 2SLS estimator. In column 3, the ODA per capita has been instrumented by its own lagged values in levels (up to four years) and a variable based on donor-government fractionaliza- 
Table 2 (continued)

tion, $\sum_{j} \bar{P}_{i j} \cdot F_{r a c}$ (Dreher et al. 2019). Additionally, in column 4 analogous instruments are used for the interaction term between ODA and governance. Full results of the first-stage regressions are available in Appendix C (Table 9).

We also present a battery of diagnostic tests on both estimated specifications, which support the validity of the chosen instruments and the 2SLS approach. ${ }^{11}$ For this reason, the following comments refer to the results obtained from the last estimator. When we exclude the interaction term (column 3), we do not find a significant impact of ODA on asylum seeking. However, the outcomes reveal a significant negative association between asylum claims from a given source country and its average level of governance quality. Moreover, our results also indicate that asylum claims are significantly dependent on the gravity variables. As expected, the number of asylum applications negatively depends on the sending country's income per capita and the geographical distance between the origin and destination countries, while it is positively linked to colonial ties and a common language. Finally, regarding the control variables for the source country, we find that the flows of asylum seekers decrease with the size of the young population, while they increase with the number of annual fatalities and the average temperature. We do not find a significant relationship between asylum seeking and the remaining control factors.

When we consider the unrestricted model (column 4), which includes de interaction between bilateral aid and governance quality, the estimated coefficients associated with governance quality and ODA are both positive, while the coefficient on their interaction is negative, all of them being significant at the $1 \%$ level. Interestingly, the statistical significance of the interaction term suggests that the effect of governance is actually dependent on the level of ODA, and vice versa. For ease of interpretation of the results, we present in Fig. 1 the estimated elasticities of asylum seeking to changes in the variables of interest, calculating the respective partial derivatives of Eq. (3) with respect to governance quality in the source country $\left(\Delta \ln \widehat{A}_{i j t} / \Delta \ln G_{i t}=\widehat{\gamma}_{1}+\widehat{\gamma}_{3} \ln O D A_{i j t}\right)$ and bilateral ODA $\left(\Delta \ln \widehat{A}_{i j t} / \Delta \ln G_{i t}=\widehat{\gamma}_{2}+\widehat{\gamma}_{3} \ln G_{i t}\right)$, considering different values of ODA and governance. The results indicate that, on the one hand, a $1 \%$ improvement in the governance quality of the origin African country results in significant decreases in the number of asylum seekers in Europe, for any positive amount of bilateral net ODA received from developed countries. This estimated negative effect becomes stronger as the country of origin receives more ODA. That is, the effectiveness of governance quality, which could eventually mitigate conflicts and instabilities, capable of causing forced migration, could be enhanced by receiving foreign aid.

\footnotetext{
${ }^{11}$ First, the Hansen $\mathrm{J}$ statistic of overidentifying restrictions fails to reject the null hypothesis that instruments are exogeneous (i.e., uncorrelated with the error term). Second, the value of the Kleibergen-Paap Wald F test statistic is higher than the rule-of-thumb value of 10 proposed by Stock and Yogo (2005), rejecting the null hypothesis of weak instruments. Third, the instruments satisfy the rank conditions because the Kleibergen-Paap LM test statistic rejects the null hypothesis that the regression is underidentified (Kleibergen and Paap, 2006). Lastly, the Durbin-Wu-Hausman statistic rejects the null hypothesis of equality between 2SLS and OLS, confirming the existence of endogeneity and the appropriateness of using 2SLS.
} 
On the other hand, the sign of the estimated impact of ODA on asylum claims critically differs depending on the level of governance quality in the source country. At relatively low levels of governance quality in the source African country, the estimated effect of a $1 \%$ increase in country i's ODA significantly raises the asylum seeking in Europe. As can be seen in Table 6, considering the average level of governance quality of each country from 1996 to 2018, countries with poor governance are the Democratic Republic of the Congo, Sudan, Central African Republic, Chad or Equatorial Guinea, among others. However, the ODA's effect on asylum seeking becomes progressively smaller as the level of governance quality increases, to the point where it becomes significantly negative when the average quality of governance is equal to or higher than $50 \%$. More specifically, our estimates show that if we consider the sample maximum level of governance quality in a source country (i.e., $77.48 \%$ ), the effect of a $1 \%$ increase in country i's ODA is to significantly decrease asylum seeking by $3.87 \%$. In accordance with Table 10, countries close to this maximum level are, for example, Mauritius, Botswana, Cape Verde, Namibia, or South Africa, among others.

Therefore, in general terms the results suggest that a stable and democratic system, with an adequate legal framework, solid institutions and free from corruption, could provide an efficient allocation of new resources from foreign aid. And this aid could be used to address the causes of forced migration, whereas the opposite is the case in countries with relatively poor governance quality. This is consistent with Kosack (2003), whose results reveal that foreign aid could have negative effects in a country's welfare unless there is an appropriate political and institutional environment. As the author argues, one possible explanation is that democratic states usually allocate aid resources to improve the welfare of their citizens, whereas autarkic states could be tempted to use the additional resources to remain in power and benefit certain élites, or even repress population (Boone 1996).

Finally, regarding the remaining explanatory variables of the unrestricted model, the significance and size of their estimated coefficients remain similar to those previously obtained with the restricted model.

\subsection{Testing the impact of EUTF}

To shed light on the effectiveness of the ODA distributed under the EU Emergency Trust Fund for Africa (EUTF, 2015-present) we extend our baseline model by decomposing the variable ODA depending on whether or not the asylum seeker's source country benefits from the aforementioned program. ${ }^{12}$ The EUTF provides development aid to target the root causes of irregular migration and displaced persons in Africa. It was established to tackle the main causes of forced and irregular migration and to improve the migration management process. The main strategic objectives are to increase employment opportunities, foster resilience of communities and improve migration management, governance and conflict prevention in the continent. Also in this case we use the 2SLS estimator with the instruments listed

\footnotetext{
12 To do this, we have constructed a dummy variable taking the value 1 for program-beneficiary countries since 2015 (see Table 5), and 0 otherwise.
} 
Table 3 Effect of governance quality and foreign aid on asylum migration (level-level model)

\begin{tabular}{|c|c|c|c|c|}
\hline \multirow[t]{2}{*}{ Dependent variable: $A_{i j t}$} & \multicolumn{2}{|l|}{ FE } & \multicolumn{2}{|l|}{ IV-FE } \\
\hline & (1) & (2) & (3) & (4) \\
\hline \multirow[t]{2}{*}{$G_{i t}$} & $-3.038^{* * *}$ & $-2.842^{* * *}$ & $-2.922^{* * *}$ & $-2.297^{* *}$ \\
\hline & $(0.877)$ & $(0.873)$ & (1.108) & $(1.141)$ \\
\hline \multirow[t]{2}{*}{$O D A_{i j t}$} & 0.025 & $6.283^{* * *}$ & -0.815 & $22.708^{* * *}$ \\
\hline & $(0.905)$ & $(1.76)$ & (1.903) & $(6.976)$ \\
\hline \multirow[t]{2}{*}{$G_{i t} \cdot O D A_{i j t}$} & & $-0.175^{* * * *}$ & & $-0.584^{* * * *}$ \\
\hline & & $(0.060)$ & & $(0.159)$ \\
\hline \multirow[t]{2}{*}{$Y_{i t}$} & $0.015^{*}$ & $0.014^{*}$ & $0.017^{* *}$ & $0.015^{*}$ \\
\hline & $(0.008)$ & $(0.008)$ & $(0.008)$ & $(0.009)$ \\
\hline \multirow[t]{2}{*}{$d i s t_{i j}$} & $-0.017^{*}$ & $-0.016^{*}$ & $-0.018^{*}$ & -0.013 \\
\hline & $(0.009)$ & $(0.009)$ & $(0.01)$ & $(0.011)$ \\
\hline \multirow[t]{2}{*}{ colony $_{i j}$} & $98.494^{*}$ & $92.648^{*}$ & $108.533^{*}$ & 72.030 \\
\hline & $(54.876)$ & $(54.711)$ & (57.604) & $(61.456)$ \\
\hline \multirow[t]{2}{*}{ clang $_{i j}$} & $147.808^{* * *}$ & $148.232^{* * *}$ & $159.210^{* * *}$ & $156.037^{* * *}$ \\
\hline & (43.259) & (43.188) & $(45.667)$ & $(48.494)$ \\
\hline \multirow[t]{2}{*}{ fatal $_{i t}$} & 0.002 & 0.002 & 0.002 & 0.002 \\
\hline & $(0.002)$ & $(0.002)$ & $(0.002)$ & $(0.002)$ \\
\hline \multirow[t]{2}{*}{ ypop $_{i t}$} & 0.001 & 0.001 & 0.001 & 0.001 \\
\hline & $(0.001)$ & $(0.001)$ & $(0.001)$ & $(0.001)$ \\
\hline \multirow[t]{2}{*}{$u r b_{i t}$} & $7.109^{*}$ & 6.686 & 7.321 & 6.477 \\
\hline & (4.173) & (4.169) & (4.927) & $(5.088)$ \\
\hline \multirow[t]{2}{*}{ agric $_{i t}$} & $1.764^{*}$ & $1.760^{*}$ & 1.182 & 1.218 \\
\hline & $(0.91)$ & $(0.91)$ & (1.009) & $(1.035)$ \\
\hline \multirow[t]{2}{*}{ employr $_{i t}$} & -3.177 & -3.267 & -3.3 & -3.257 \\
\hline & (2.309) & $(2.3)$ & $(2.68)$ & $(2.757)$ \\
\hline \multirow[t]{2}{*}{ temp $p_{i t}$} & 10.681 & 10.207 & $26.901^{*}$ & $24.790^{*}$ \\
\hline & (12.985) & (12.938) & (14.715) & $(14.773)$ \\
\hline \multirow[t]{2}{*}{ precip $_{i t}$} & 0.196 & 0.202 & 0.136 & 0.145 \\
\hline & $(0.187)$ & $(0.186)$ & (0.193) & $(0.194)$ \\
\hline \multirow[t]{2}{*}{ Hansen $\mathrm{J}$ test } & & & 0.218 & 3.604 \\
\hline & & & [0.995] & {$[0.824]$} \\
\hline \multirow[t]{2}{*}{ Kleibergen-Paap rk LM test } & & & 9.920 & 52.678 \\
\hline & & & {$[0.076]$} & {$[0.000]$} \\
\hline Kleibergen-Paap rk Wald F & & & 27.696 & 9.264 \\
\hline $\mathrm{R}^{2}$ & 0.207 & 0.188 & & \\
\hline AIC & 318,489 & 318,447 & 285,179 & 285,232 \\
\hline Obs. (NxT) & 21,220 & 21,220 & 18,877 & 18,877 \\
\hline
\end{tabular}

All regressions include origin (i) and destination-year (jt) fixed effects. Sampled period ranges from 1996 to 2018. Heteroskedasticity- and autocorrelation-consistent s.e. are presented in parentheses, while pvalues are in brackets. We use ${ }^{*}{ }^{* *}$, and ${ }^{* * *}$ to denote statistical significance at the $10 \%, 5 \%$, and $1 \%$ levels, respectively. The IV-FE refers to the 2 SLS estimator. In column 3, the ODA per capita has been instrumented by its own lagged values in levels (up to four years) and a variable based on donor-government fractionalization, $\sum_{j} \bar{P}_{i j} \cdot$ Frac $_{j t}$ (Dreher et al. 2019). Additionally, in column 4 analogous instruments are used for the interaction term between ODA and governance. 

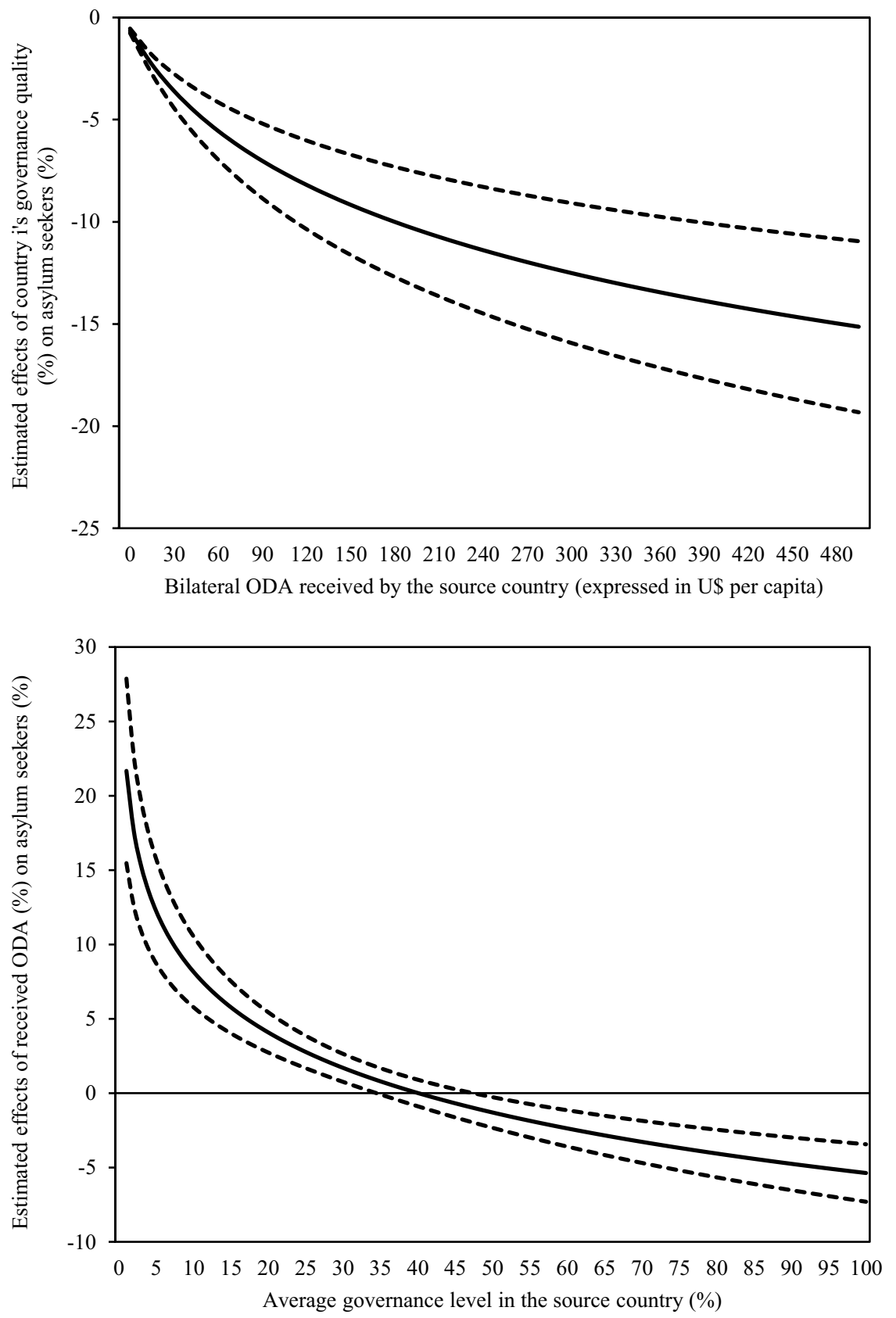

Note: Dashed lines represent the confidence intervals at $90 \%$. Figures are based on the estimated coefficients shown in column (4) of Table 2.

Fig. 1 Estimated elasticities from the 2SLS regression of the log-log model 


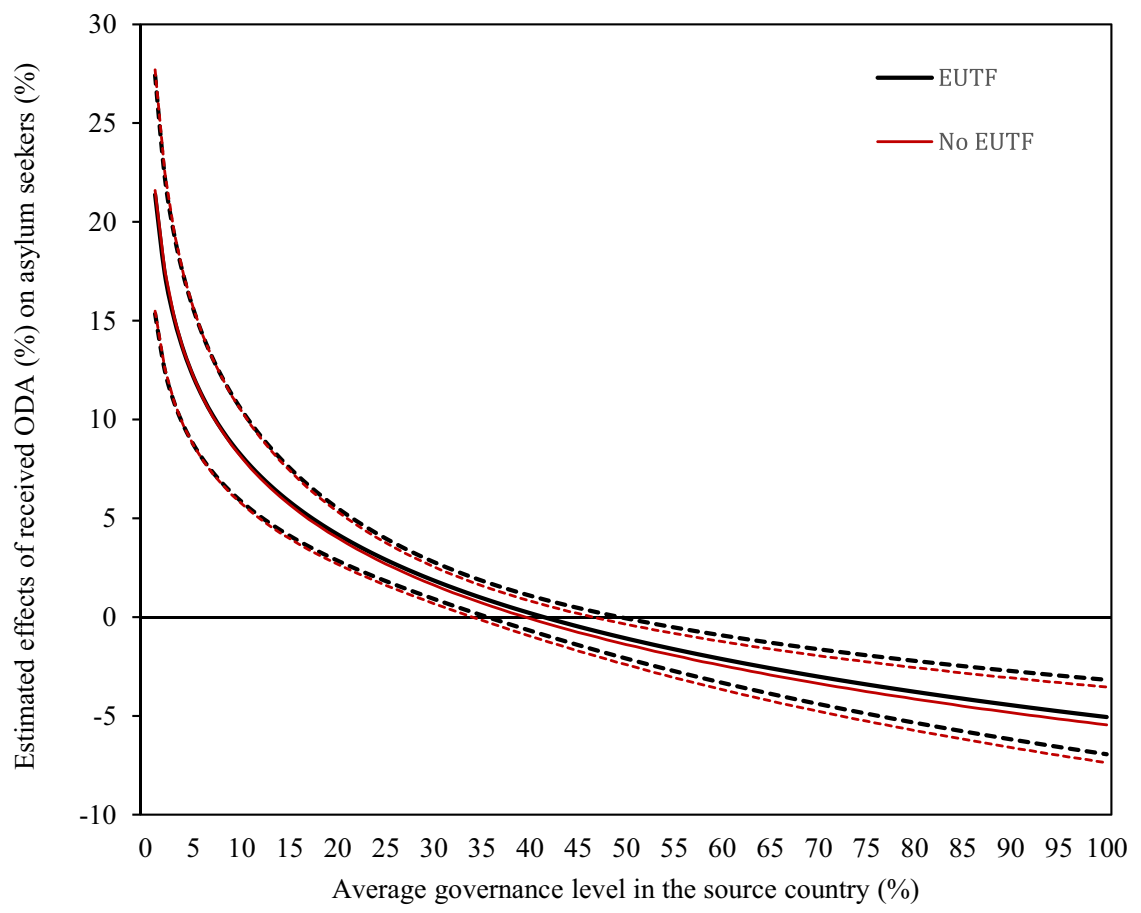

Note: Dashed lines represent the confidence intervals at $90 \% . \mathrm{EUTF}=$ countries beneficiaries of the European Union Emergency Trust Fund.

Fig. 2 Estimated elasticities from the 2SLS model (log-log model, EUTF and the rest of African countries)

above. ${ }^{13}$ Then, we use these estimates to construct the predicted effects of ODA on asylum seeking, distinguishing between EUTF and non-EUTF beneficiary countries (listed in footnote ${ }^{3}$ ). As can be seen in Fig. 2, the estimated effects of ODA on asylum claims remain largely unchanged with respect to those obtained in the baseline model in the previous section. Moreover, the overlap of the confidence intervals in the different levels of governance quality indicates that the effect of ODA on asylum seeking from EUTF beneficiaries does not differ significantly from that on flows from the non-EUTF beneficiaries. Therefore, our results cannot confirm the effectiveness of the program in deterring asylum applications through the development

\footnotetext{
${ }^{13}$ For reasons of space, these estimated results are not shown here, but they are available from the authors on request.
} 
Table 4 Effect of governance quality and foreign aid on asylum migration (PPML model)

\begin{tabular}{|c|c|c|c|c|c|c|}
\hline \multirow[t]{2}{*}{ Dependent variable: $A_{i j t}$} & \multicolumn{2}{|l|}{ PPML } & \multicolumn{4}{|l|}{ IV-PPML } \\
\hline & (1) & (2) & (3) & & (4) & \\
\hline \multirow[t]{2}{*}{$\ln G_{i t}$} & $-0.908^{* * *}$ & $2.598^{* *}$ & $-0.858^{* * *}$ & & $8.198^{* * *}$ & \\
\hline & $(0.089)$ & $(1.233)$ & $(0.065)$ & & $(0.880)$ & \\
\hline \multirow[t]{2}{*}{$\ln O D A_{i j t}$} & $0.701^{* * *}$ & $3.076^{* * *}$ & $2.638^{* * *}$ & & $8.461^{* * *}$ & \\
\hline & (0.194) & $(0.893)$ & (0.339) & & $(0.629)$ & \\
\hline \multirow[t]{2}{*}{$\ln G_{i t} \cdot \ln O D A_{i j t}$} & & $-0.903^{* * *}$ & & & $-2.345^{* * *}$ & \\
\hline & & $(0.323)$ & & & $(0.226)$ & \\
\hline \multirow[t]{2}{*}{$\ln Y_{i t}$} & -0.307 & -0.323 & -0.391 & & $-0.407^{* * *}$ & \\
\hline & $(0.241)$ & $(0.238)$ & $(0.282)$ & & $(0.033)$ & \\
\hline \multirow[t]{2}{*}{ lndist $_{i j}$} & $0.621^{*}$ & $0.583^{*}$ & 0.666 & & 0.599 & \\
\hline & $(0.339)$ & $(0.329)$ & $(0.591)$ & & $(0.621)$ & \\
\hline \multirow[t]{2}{*}{ colony $_{i j}$} & $0.258^{* * *}$ & $0.290^{* * *}$ & 0.069 & & $0.187^{* * *}$ & \\
\hline & $(0.091)$ & $(0.09)$ & $(0.075)$ & & $(0.001)$ & \\
\hline \multirow[t]{2}{*}{ clang $_{i j}$} & $0.903^{* * *}$ & $0.903^{* * *}$ & $0.864^{* * *}$ & & $0.891^{* * *}$ & \\
\hline & $(0.095)$ & $(0.095)$ & $(0.068)$ & & $(0.071)$ & \\
\hline \multirow[t]{2}{*}{$\operatorname{lnfatal}_{i t}$} & $0.036^{* *}$ & $0.037^{* *}$ & $0.036^{* *}$ & & $0.040^{* * *}$ & \\
\hline & $(0.015)$ & $(0.015)$ & $(0.016)$ & & $(0.011)$ & \\
\hline \multirow[t]{2}{*}{ lnypop $_{i t}$} & 0.175 & 0.187 & $0.179^{* *}$ & & 0.199 & \\
\hline & $(0.352)$ & $(0.351)$ & $(0.070)$ & & $(0.55)$ & \\
\hline \multirow[t]{2}{*}{$\operatorname{lnurb}_{i t}$} & $1.044^{*}$ & 0.960 & $0.912^{* * *}$ & & $0.773^{*}$ & \\
\hline & $(0.617)$ & $(0.613)$ & $(0.071)$ & & $(0.433)$ & \\
\hline \multirow[t]{2}{*}{ lnagric $_{i t}$} & -0.030 & -0.039 & -0.087 & & -0.086 & \\
\hline & $(0.141)$ & $(0.140)$ & $(0.463)$ & & $(0.098)$ & \\
\hline \multirow[t]{2}{*}{ lnemployr $_{i t}$} & $-1.622^{* * *}$ & $-1.585^{* * *}$ & $-1.800^{* * *}$ & & $-1.655^{*}$ & \\
\hline & $(0.585)$ & $(0.585)$ & $(0.512)$ & & $(0.925)$ & \\
\hline \multirow[t]{2}{*}{ lntemp $_{i t}$} & $7.726^{* * *}$ & $7.952^{* * *}$ & $11.392^{* * * *}$ & & $11.822^{* * * *}$ & \\
\hline & $(2.968)$ & $(2.957)$ & (1.949) & & $(1.583)$ & \\
\hline \multirow[t]{2}{*}{ lnprecip $_{i t}$} & 0.161 & 0.155 & $0.200^{*}$ & & $0.193^{* * *}$ & \\
\hline & $(0.219)$ & $(0.217)$ & $(0.106)$ & & $(0.056)$ & \\
\hline Pseudo- $\mathrm{R}^{2}$ & 0.774 & 0.775 & & & & \\
\hline AIC & $1,970,000$ & $1,960,000$ & & $1,840,000$ & & $1,830,000$ \\
\hline Obs. (NxT) & 21,220 & 21,220 & & 18,877 & & 18,877 \\
\hline
\end{tabular}

All regressions include origin (i) and destination-year (jt) fixed effects. Sampled period ranges from 1996 to 2018 . Robust s.e. are presented in parentheses. We use ${ }^{*},{ }^{* *}$, and ${ }^{* * *}$ to denote statistical significance at the $10 \%, 5 \%$, and $1 \%$ levels, respectively. The IV-PPML refers to the PPML estimator combined with the control-function approach suggested by Wooldridge (2015), which makes it possible to deal with endogeneity in nonlinear models. In column 3, the ODA per capita has been instrumented by its own lagged values in levels (up to four years) and a variable based on donor-government fractionalization, $\sum_{j} \bar{P}_{i j} \cdot F_{r a c}$ (Dreher et al. 2019). Additionally, in column 4 analogous instruments are used for the interaction term between ODA and governance. 

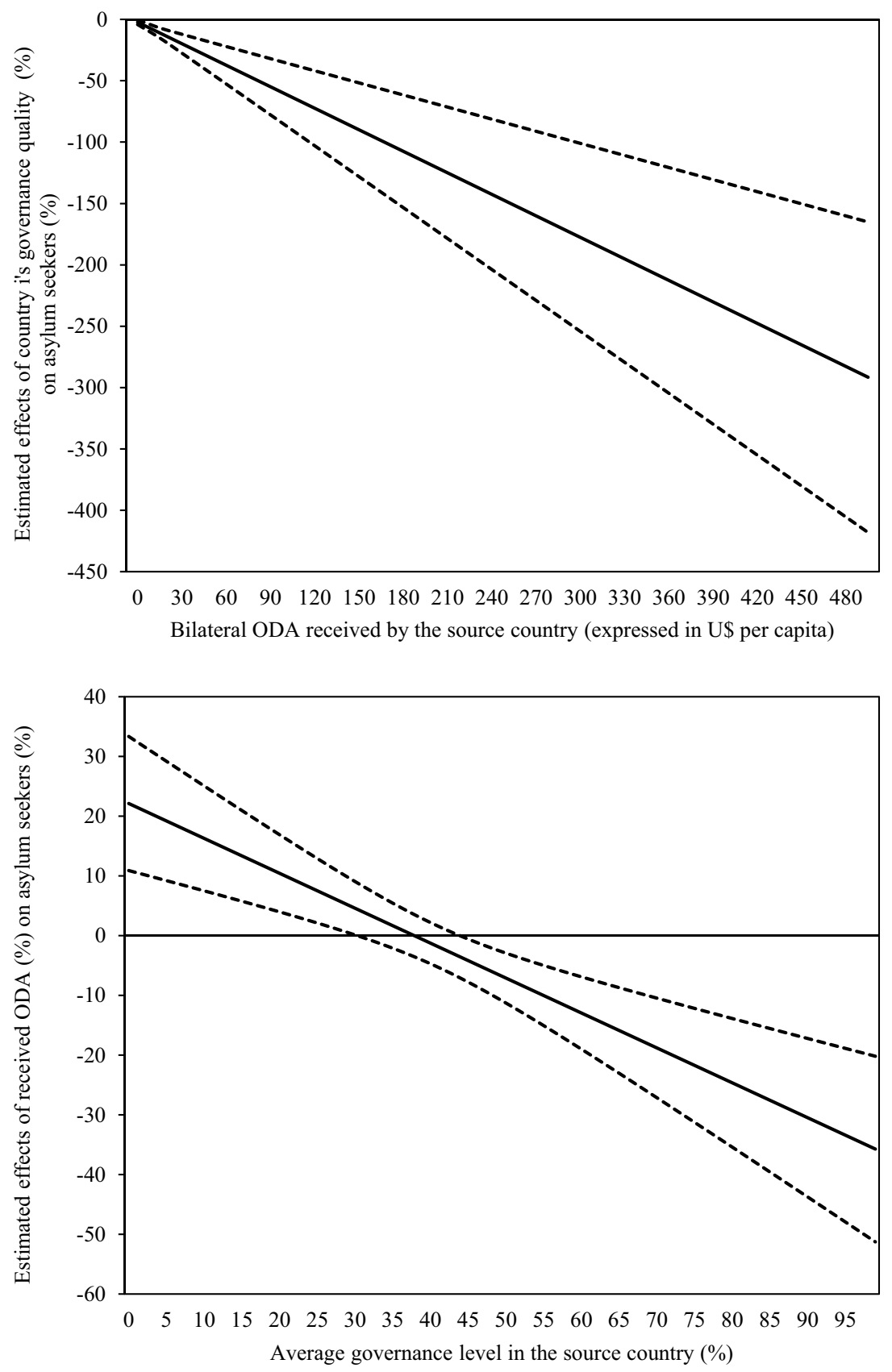

Note: Dashed lines represent the confidence intervals at $90 \%$. Figures are based on the estimated coefficients shown in column (4) of Table 3.

Fig. 3 Estimated elasticities from the 2SLS regression (level-level model) 

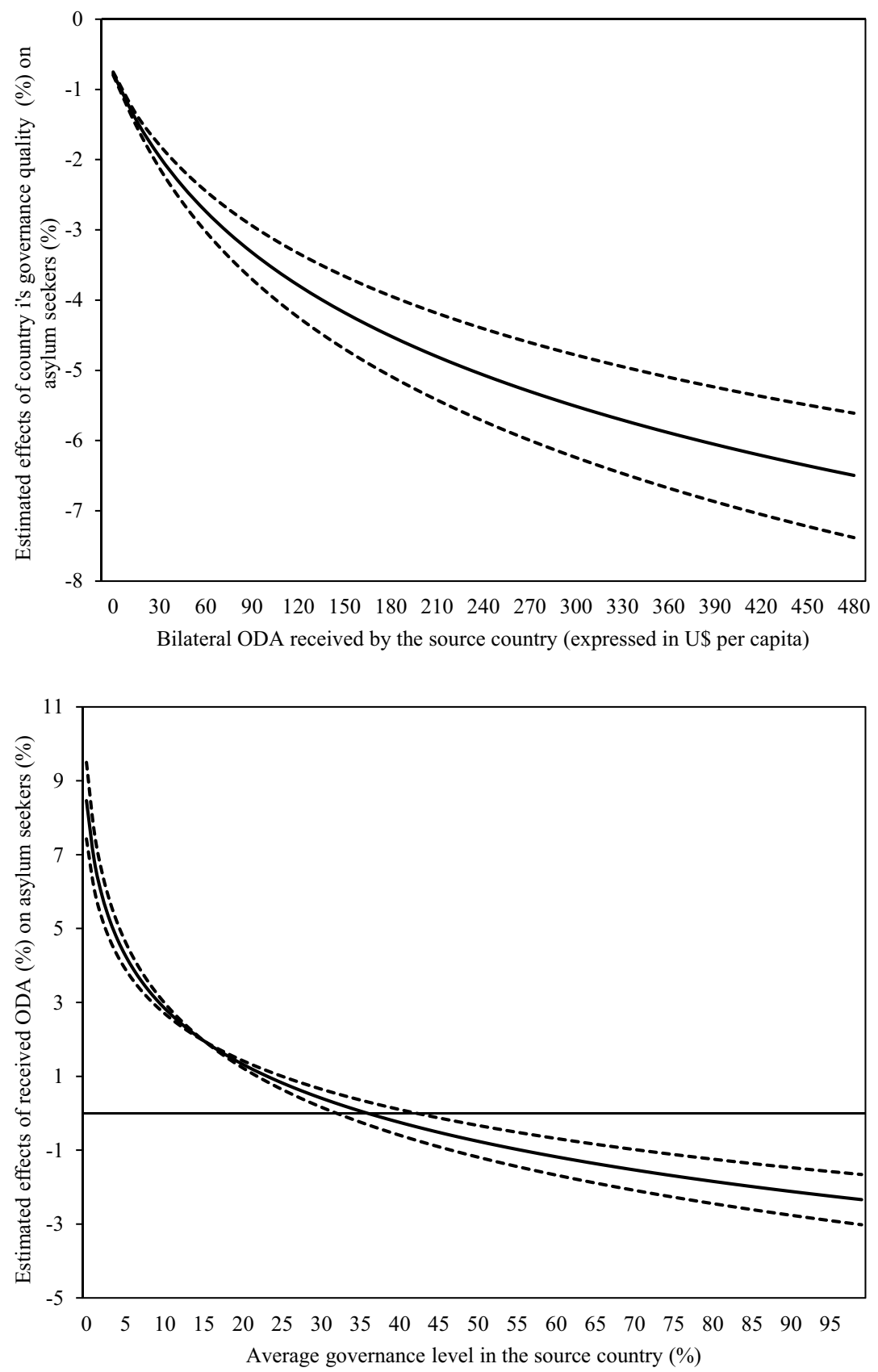

Note: Dashed lines represent the confidence intervals at $90 \%$. Figures are based on the estimated coefficients shown in column (4) of Table 4.

Fig. 4 Estimated elasticities (IV-PPML model) 
of the origin countries and the regulation of migration flows. That said, we acknowledge that it could be too soon to obtain a significant result, given that the programs only started in 2015 and hence further evaluations should be done once data for subsequent years become available.

\subsection{Robustness checks}

In order to assess the sensitivity of our results, we now replicate the analysis using the two abovementioned robustness exercises. First, we re-estimate the gravity model considering all variables in levels, given by Eq. (4), with OLS and 2SLS. Second, we estimate Eq. (5) using the PPML estimator, which accounts for zero values of the dependent variable and heteroskedasticity in the error term that is inherent to the loglinearization of the gravity model. We also use the PPML with the instrumental variables (PPML-IV) via the control-function approach. Table 3 and 4 present, respectively, the estimated results. Additionally, Fig. 3 presents the corresponding effects derived from the 2SLS estimates of Eq. (4) in levels, while Fig. 4 displays those derived from the PPML-IV estimates of Eq. (5). Although the estimated coefficients and estimated elasticities from different approaches are not directly comparable, the obtained results remain quite consistent in both cases. It is worth mentioning that the variable young population has now the expected positive sign reporter in the related literature, whereas in Table 2 it shows a negative and significant coefficient. With respect to the target variables, when the origin country of asylum seekers receives a positive amount of bilateral net ODA, the results indicate that governance quality significantly decreases the asylum claims and that this effect becomes stronger as the amount of received ODA increases. Additionally, we find that more ODA significantly decreases asylum applications when the level of governance quality in the source country is high enough. ${ }^{1415}$

\footnotetext{
${ }^{14}$ The OLS and 2SLS estimates have been obtained using the Stata commands reghdfe and ivreghdfe, respectively, while PPML regressions have been fitted with the command ppmlhdfe (Correia et al. 2020).

15 Recent literature supports that people whose main reason to emigrate is persecution and/or conflict could be positively self-selected regarding the country-of-origin population in terms of their educational level (e.g., Aksoy and Poutvaara 2019). Additionally, the acquired education could influence people perception about the quality of the institutions and their decisions where to live. Following the recommendation of an anonymous referee, in Appendix D we include some robustness checks considering the potential role of education in the asylum-seeking process and its plausible interdependence with governance quality. In general terms, our main results remain unchanged, being poor governance quality a relevant push factor for asylum seekers, for virtually any educational level in the source country.
} 


\section{Conclusions and Policy Recommendations}

This paper investigates the effect of governance quality in the country of origin on asylum migration from African countries to EU countries over the last two decades. Moreover, it examines the role of development aid -ODA in particular- and its interplay with the quality of governance as determinants of asylum flows. Finally, the effectiveness of the European Union Emergency Trust Fund (EUTF) for Africa, which was intended to deter migration, is evaluated.

Our empirical results suggest that the number of asylum seekers is strongly determined by poor governance and political instability in the country of origin, and that the effect of governance depends on the amount of aid received from developed countries. In particular, for any positive amount of bilateral net ODA received, we find that good governance in African countries significantly reduces migration outflows toward Europe, with its effect being stronger the more foreign aid is received. This is consistent with other previous empirical studies reporting evidence of the importance of poor governance and political instability as the main driver of asylum seeker outflows (Kang 2021). Regarding the effect of foreign aid on asylum seeking migration flows, according to our results ODA is only effective in reducing asylum applications when the governance quality in the recipient country is good enough. In contrast, ODA could generate counterproductive effects in recipient countries with an average quality of governance index lower than 50\%. These conclusions hold regardless of whether or not the recipient country benefits from the EUTF. Therefore, a policy recommendation that can be extracted from our results is that increasing development aid towards countries with good governance quality could help reducing the number of asylum seekers. In this regard, it is important that countries also devote efforts to improve governance quality, objective which could also be achieved dedicating part of the aid received to it. Nevertheless, external and ex-post policy evaluation is also required to guarantee that aid is allocated and spent in the acquired commitments.

This study provides some insights that could be useful for policymakers. Our findings show that foreign aid allocation from European donors to Africa could be better channeled to reduce forced migration from those countries with sound institutional quality and good governance. In this regard, Europe should collaborate with Africa not only in terms of providing assistance aimed at fostering economic and welfare development, but also by promoting its governance quality.

We leave for further research a closer look at more specific development aid flows and their importance for addressing the issue of asylum seeking in the countries of origin. 


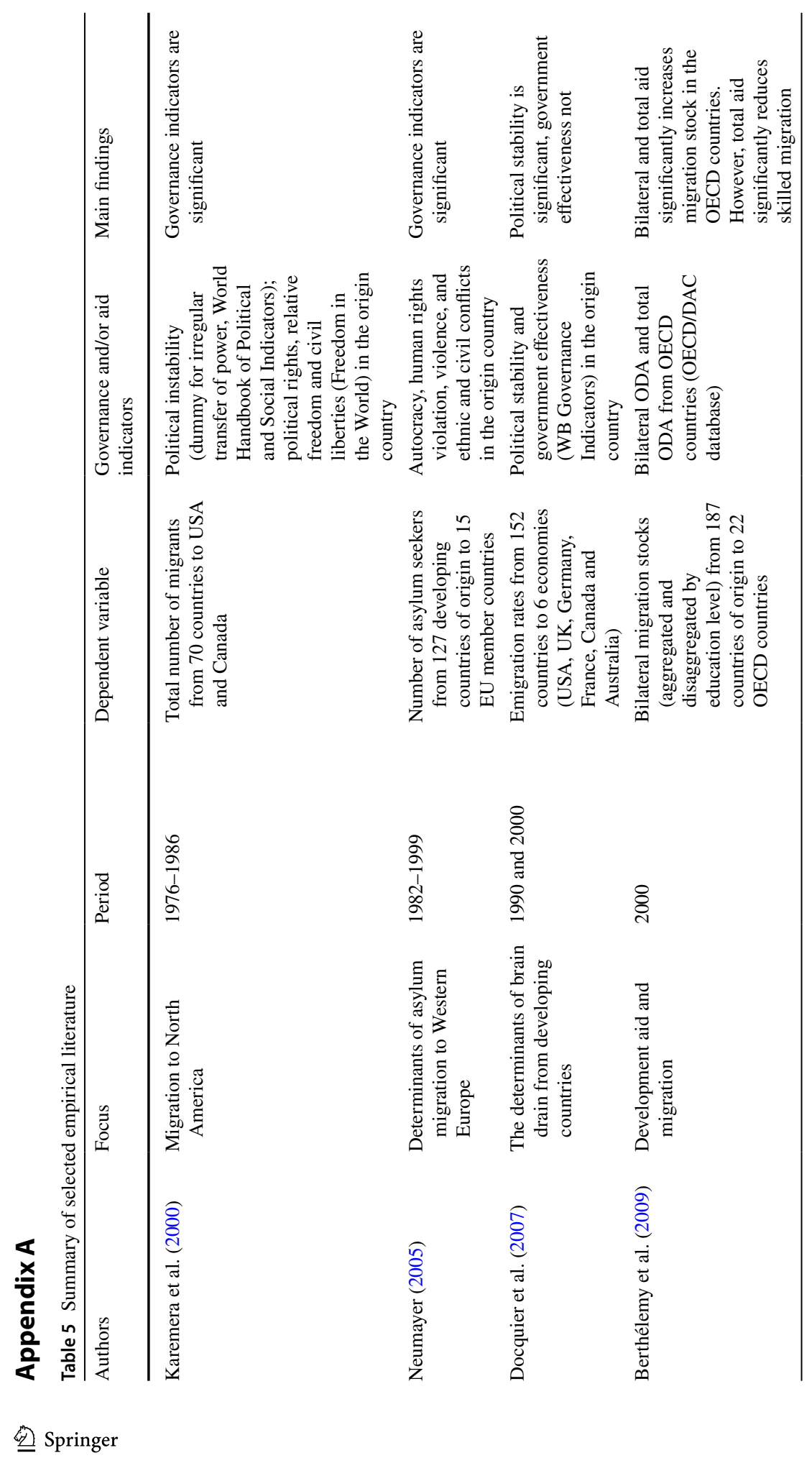




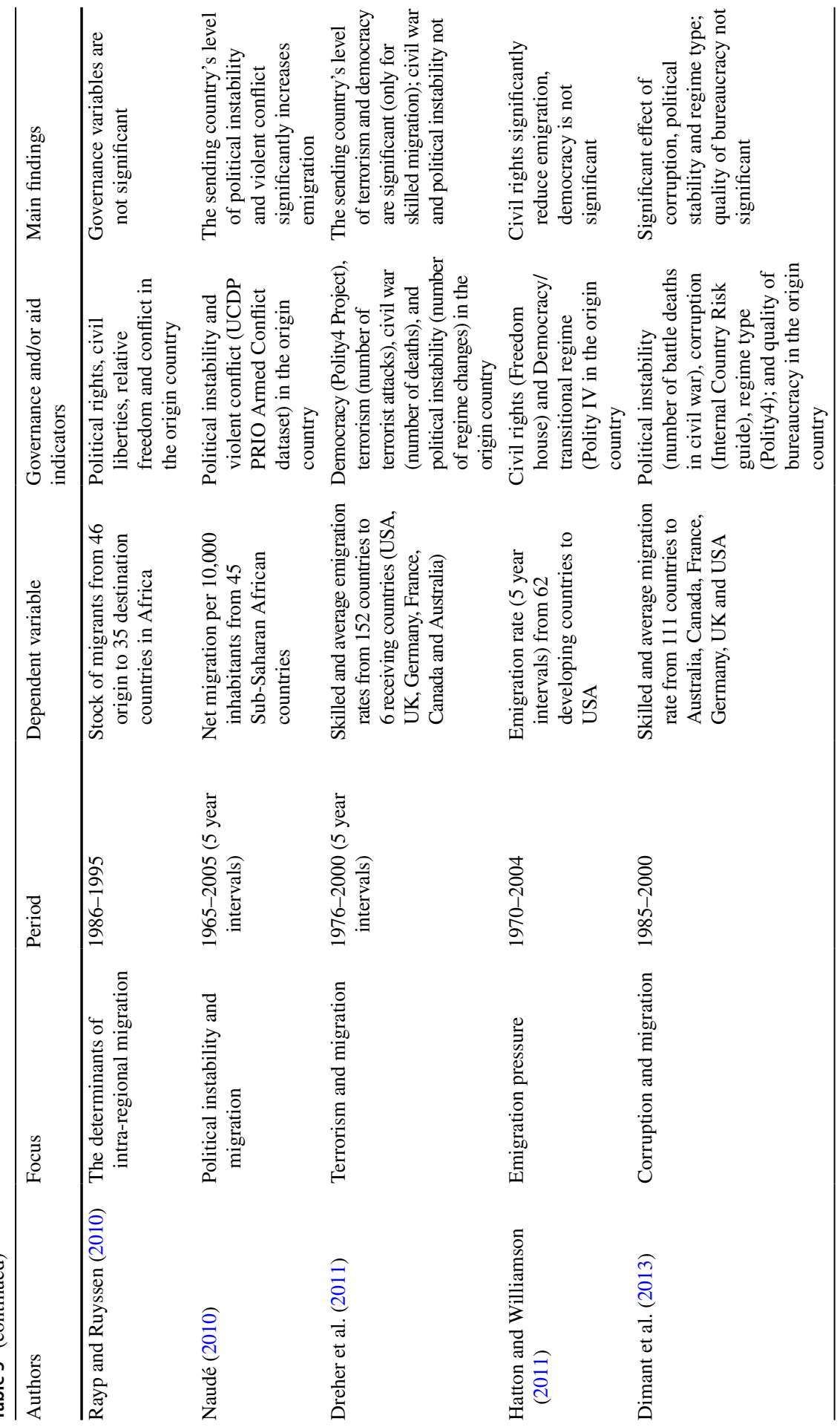




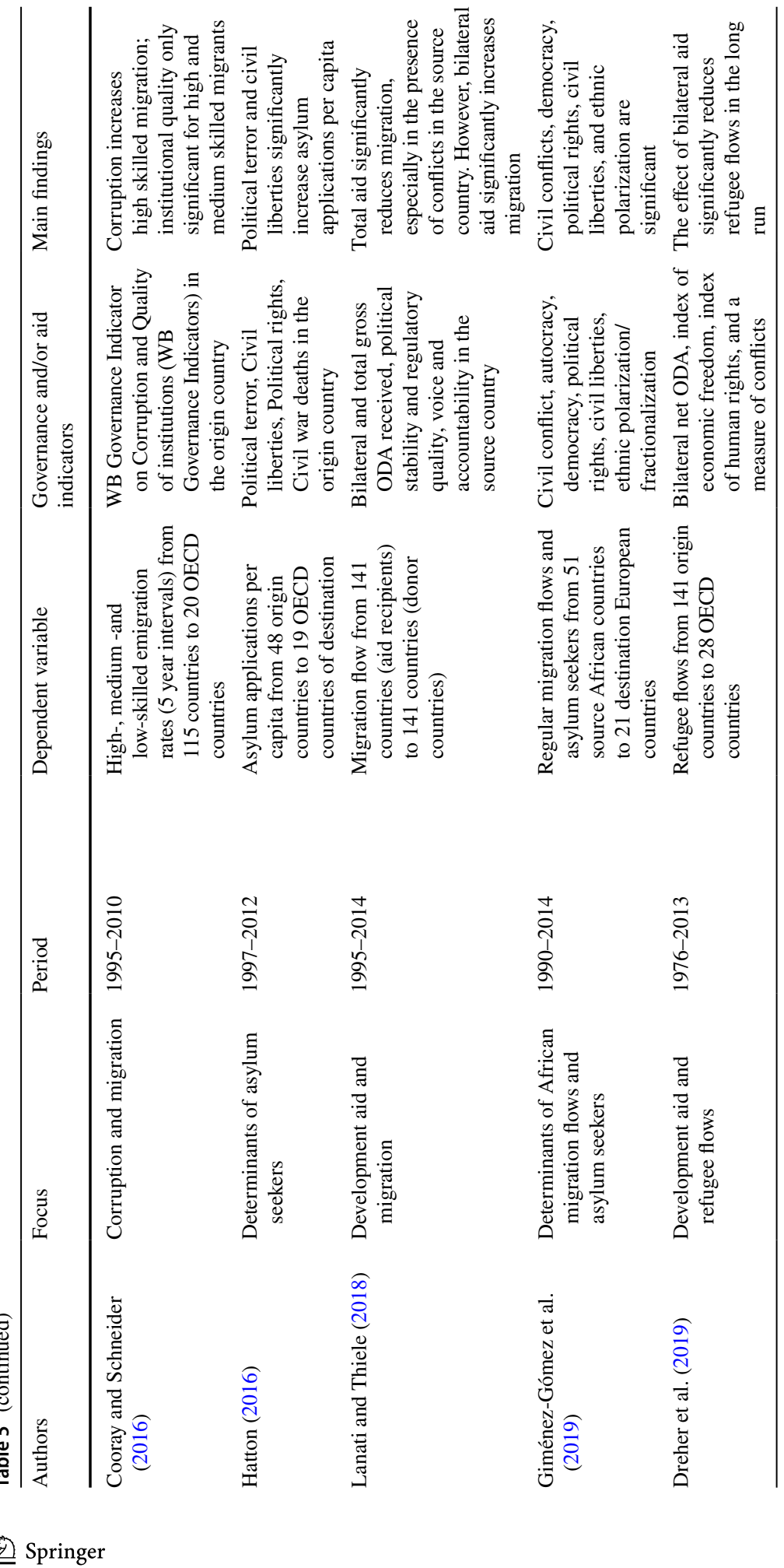




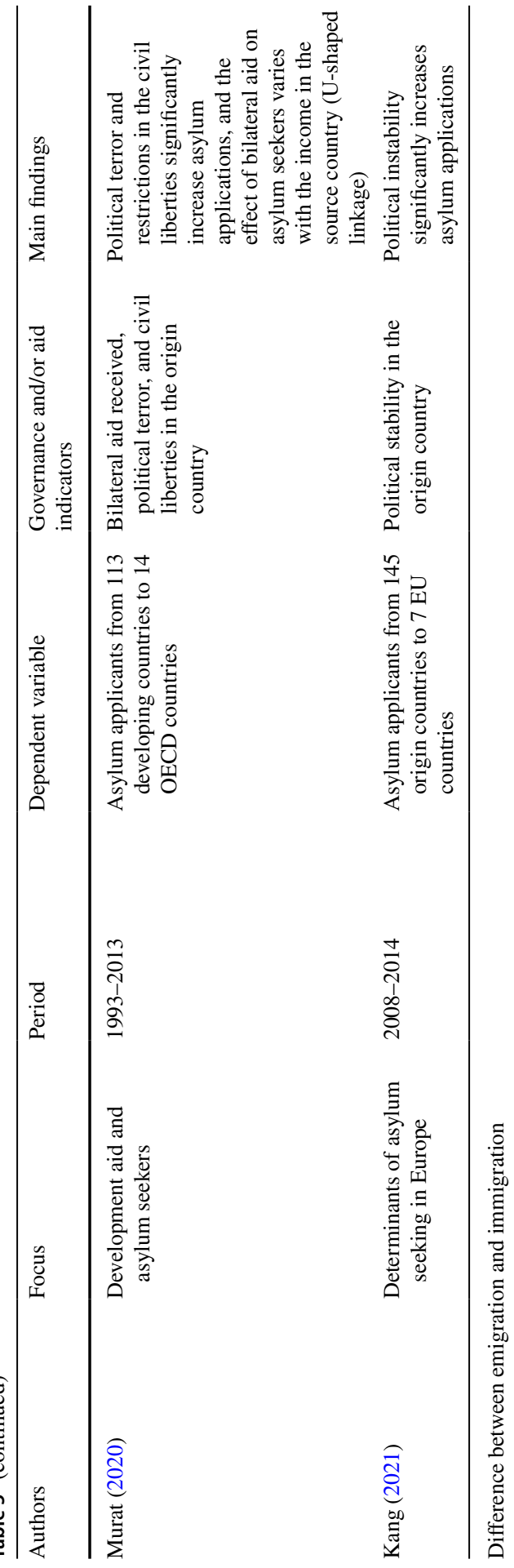




\section{Appendix B}

Table 6 List of countries and average levels of governance quality for source countries

\begin{tabular}{|c|c|c|c|}
\hline $\begin{array}{l}\text { Source countries (recipient } \\
\text { countries) }\end{array}$ & & & $\begin{array}{l}\text { Destination (donor } \\
\text { countries) }\end{array}$ \\
\hline 1. Algeria [22.159] & 25. Lesotho [46.227] & $\begin{array}{l}\text { 49. Uganda } \\
\text { [31.247] }\end{array}$ & 1. Austria \\
\hline 2. Angola [11.819] & 26. Liberia [15.204] & $\begin{array}{c}\text { 50. Zambia } \\
{[37.733]}\end{array}$ & 2. Belgium \\
\hline 3. Benin [44.641] & 27. Libya [13.241] & $\begin{array}{l}\text { 51. Zimbabwe } \\
\text { [12.636] }\end{array}$ & 3. Czech Republic \\
\hline 4. Botswana [72.991] & $\begin{array}{l}\text { 28. Madagascar } \\
\text { [34.751] }\end{array}$ & & 4. Denmark \\
\hline 5. Burkina Faso [31.122] & 29. Malawi [38.699] & & 5. Estonia \\
\hline 6. Burundi [11.679] & 30. Mali [35.347] & & 6. Finland \\
\hline 7. Cameroon [18.124] & $\begin{array}{l}\text { 31. Mauritania } \\
\text { [31.154] }\end{array}$ & & 7. France \\
\hline 8. Cape Verde [67.261] & 32. Mauritius [74.065] & & 8. Germany \\
\hline $\begin{array}{l}\text { 9. Central African Republic } \\
\text { [10.122] }\end{array}$ & 33. Morocco [44.777] & & 9. Greece \\
\hline 10. Chad [10.684] & $\begin{array}{l}\text { 34. Mozambique } \\
{[36.243]}\end{array}$ & & 10. Hungary \\
\hline 11. Comoros [20.892] & 35. Namibia [62.387] & & 11. Ireland \\
\hline 12. Congo [13.323] & 36. Niger [28.271] & & 12. Italy \\
\hline 13. Côte d'Ivoire [22.127] & 37. Nigeria [15.208] & & 13. Latvia \\
\hline $\begin{array}{l}\text { 14. Democratic Republic of the } \\
\text { Congo [3.885] }\end{array}$ & 38. Rwanda [32.894] & & 14. Lithuania \\
\hline 15. Egypt [32.042] & $\begin{array}{l}\text { 39. Sao Tome and } \\
\text { Principe [44.118] }\end{array}$ & & 15. Luxembourg \\
\hline 16. Equatorial Guinea [11.571] & 40. Senegal $[46.548]$ & & 16. Netherlands \\
\hline 17. Eritrea [16.862] & 41. Seychelles [59.694] & & 17. Norway \\
\hline 18. Ethiopia [20.815] & $\begin{array}{l}\text { 42. Sierra Leone } \\
{[20.666]}\end{array}$ & & 18. Poland \\
\hline 19. Gabon [34.544] & $\begin{array}{l}\text { 43. South Africa } \\
\text { [61.524] }\end{array}$ & & 19. Portugal \\
\hline 20. Gambia [35.502] & 44. Sudan [6.108] & & 20. Slovak Republic \\
\hline 21. Ghana [51.309] & 45. Swaziland [32.395] & & 21. Slovenia \\
\hline 22. Guinea [14.444] & 46. Tanzania [35.749] & & 22. Spain \\
\hline 23. Guinea-Bissau [14.054] & 47. Togo [21.714] & & 23. Sweden \\
\hline 24. Kenya [28.161] & 48. Tunisia [47.531] & & 24. United Kingdom \\
\hline
\end{tabular}

The sample average level of the governance quality in each source country (Git) is reported between brackets. Countries that have received assistance under the EUTF program are in bold 


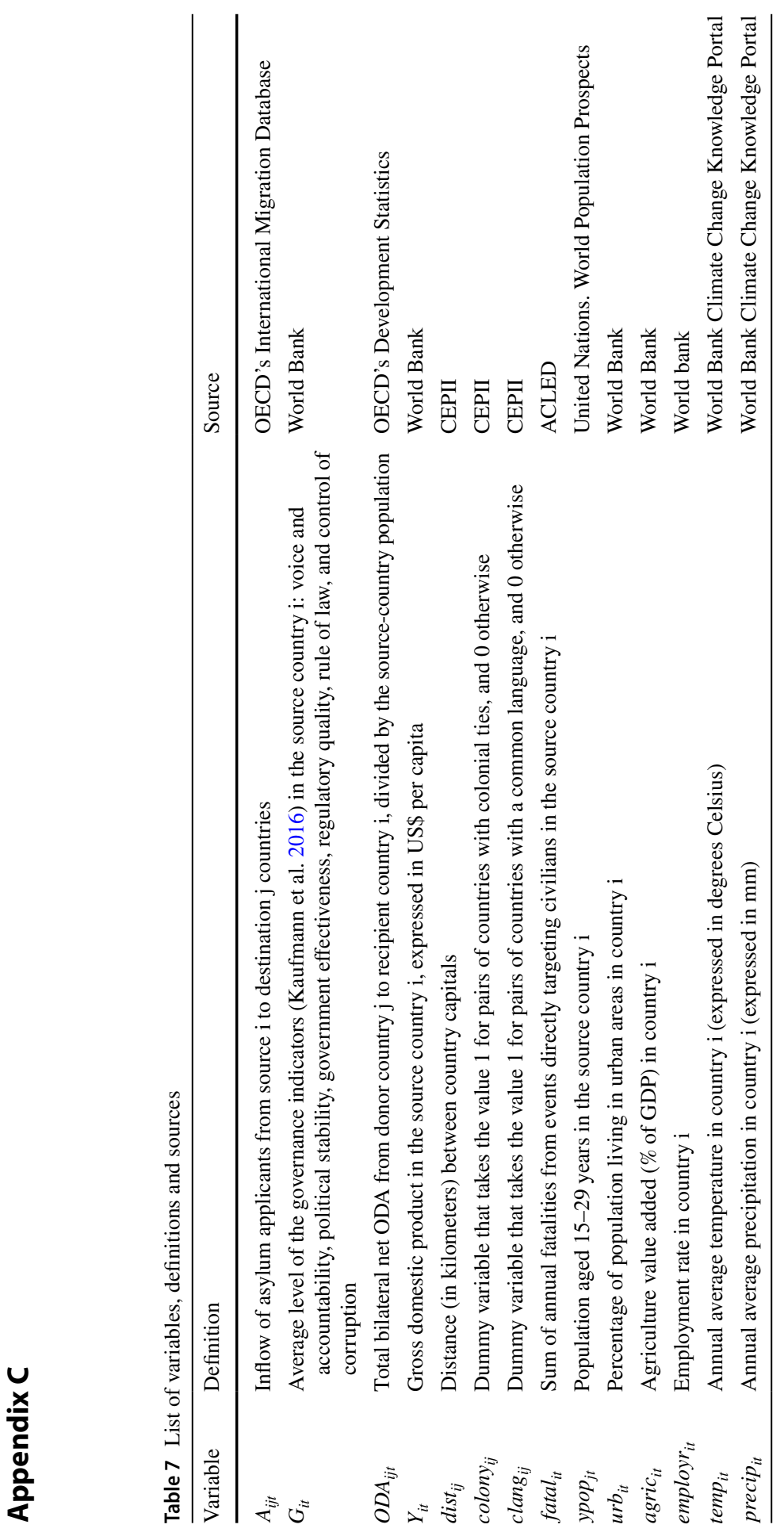




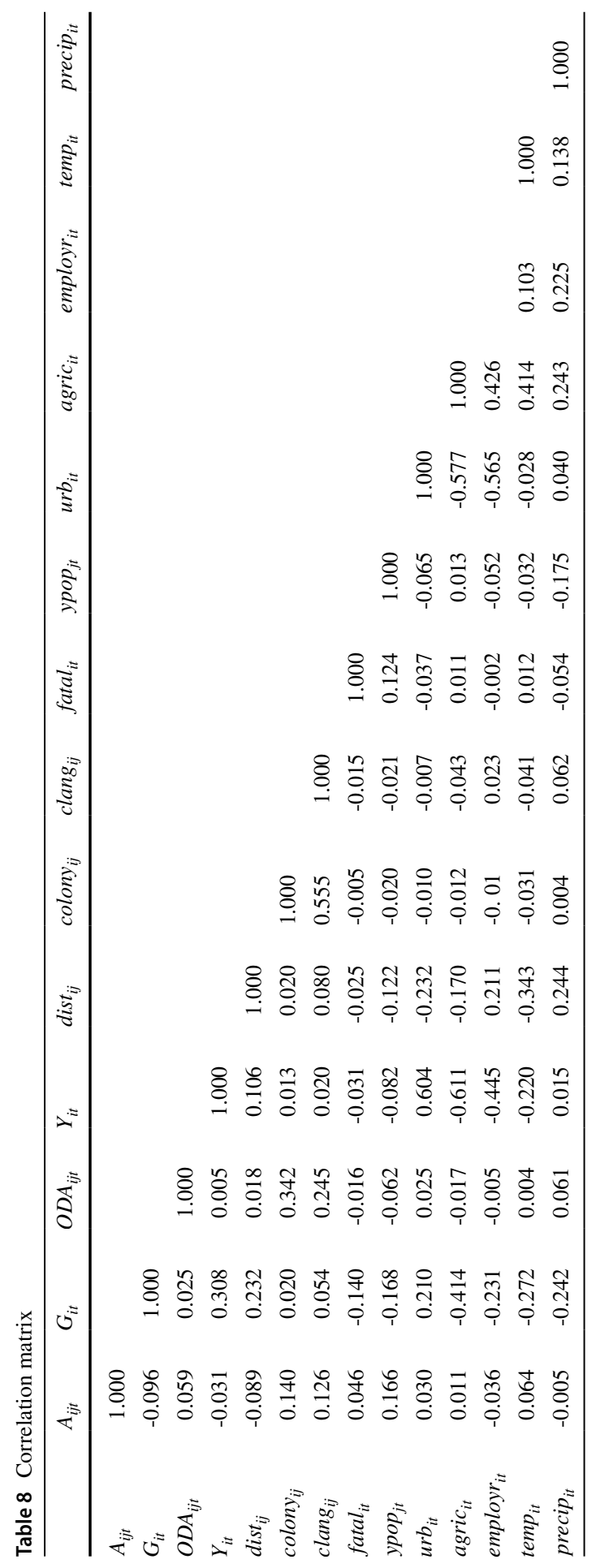


Table 9 First-stage results for 2SLS regressions

\begin{tabular}{|c|c|c|c|}
\hline & \multirow{2}{*}{$\begin{array}{l}\text { Restricted model } \\
\text { (1) }\end{array}$} & \multicolumn{2}{|c|}{ Unrestricted model } \\
\hline & & (2) & (3) \\
\hline \multirow{3}{*}{$\begin{array}{l}\text { Dep. variable: } \\
O D A_{i j t-1}\end{array}$} & $\ln O D A_{i j t}$ & $\ln O D A_{i j t}$ & $\ln G_{i t} \cdot \ln O D A_{i j t}$ \\
\hline & $1.443^{*}$ & $1.820^{* * *}$ & 3.128 \\
\hline & $(0.865)$ & $(0.9123)$ & (3.325) \\
\hline \multirow[t]{2}{*}{$O D A_{i j t-2}$} & $1.763^{* * *}$ & 1.214 & 3.384 \\
\hline & $(0.549)$ & $(1.000)$ & (3.334) \\
\hline \multirow{2}{*}{$O D A_{i j t-3}$} & $1.833^{* * *}$ & $2.402^{*}$ & $6.846^{*}$ \\
\hline & $(0.362)$ & $(1.271)$ & $(4.078)$ \\
\hline \multirow[t]{2}{*}{$O D A_{i j t-4}$} & $2.392^{* * * *}$ & $3.245^{* *}$ & $8.300^{*}$ \\
\hline & $(0.728)$ & $(1.529)$ & (4.327) \\
\hline \multirow{2}{*}{$O D A_{i j t-1} \cdot G_{i t}$} & & -0.001 & 0.051 \\
\hline & & $(0.011)$ & $(0.049)$ \\
\hline \multirow{2}{*}{$O D A_{i j t-2} \cdot G_{i t}$} & & 0.015 & 0.089 \\
\hline & & $(0.019)$ & $(0.067)$ \\
\hline \multirow[t]{2}{*}{$O D A_{i j t-3} \cdot G_{i t}$} & & -0.010 & -0.00 \\
\hline & & $(0.023)$ & $(0.077)$ \\
\hline \multirow[t]{2}{*}{$O D A_{i j t-4} \cdot G_{i t}$} & & -0.020 & -0.001 \\
\hline & & $(0.029)$ & $(0.096)$ \\
\hline \multirow{2}{*}{$\sum_{j} \bar{P}_{i j} \cdot$ Frac $_{j t}$} & -0.001 & -0.001 & -0.001 \\
\hline & $(0.003)$ & $(0.004)$ & $(0.010)$ \\
\hline \multirow[t]{2}{*}{$\ln G_{i t}$} & -0.370 & -3.392 & $3838.714^{* * *}$ \\
\hline & (1.777) & $(3.847)$ & $(5.440)$ \\
\hline \multirow[t]{2}{*}{$\ln Y_{i t}$} & -3.140 & -3.390 & -9.58 \\
\hline & $(3.847)$ & $(3.847)$ & $(9.872)$ \\
\hline \multirow[t]{2}{*}{$\operatorname{lndist}_{i j}$} & $-9.990^{* * * *}$ & $-9.710^{* * * *}$ & $-25.8^{* * * *}$ \\
\hline & $(2.501)$ & $(2.512)$ & (7.898) \\
\hline \multirow[t]{2}{*}{ colony $_{i j}$} & $46.380^{* * * *}$ & $44.310^{* * *}$ & $135.1^{* * *}$ \\
\hline & (7.068) & (8.163) & (28.00) \\
\hline \multirow[t]{2}{*}{ clang $_{i j}$} & 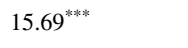 & 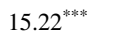 & $49.67^{* * * *}$ \\
\hline & $(3.793)$ & (3.957) & (15.14) \\
\hline \multirow[t]{2}{*}{$\operatorname{lnfatal}_{i t}$} & -0.020 & -0.010 & 0.101 \\
\hline & $(0.231)$ & $(0.224)$ & $(0.625)$ \\
\hline \multirow[t]{2}{*}{ lnypop $_{i t}$} & -4.310 & -2.420 & -11.6 \\
\hline & $(8.182)$ & (7.907) & $(22.37)$ \\
\hline \multirow[t]{2}{*}{$\operatorname{lnurb}_{i t}$} & -0.670 & -3.240 & 0.278 \\
\hline & (9.889) & $(9.702)$ & $(28.36)$ \\
\hline \multirow[t]{2}{*}{ lnagric $_{i t}$} & -1.530 & -1.810 & -3.62 \\
\hline & $(2.703)$ & (2.639) & $(7.225)$ \\
\hline \multirow[t]{2}{*}{ lnemployr $_{i t}$} & $31.64^{* *}$ & $30.100^{* *}$ & $88.49^{* *}$ \\
\hline & $(13.15)$ & (13.07) & (37.28) \\
\hline \multirow[t]{2}{*}{ lntemp $_{i t}$} & -34.60 & -34.800 & -116 \\
\hline & $(35.390)$ & $(35.660)$ & (106.4) \\
\hline \multirow[t]{2}{*}{ lnprecip $_{i t}$} & -1.590 & -1.440 & -7.56 \\
\hline & (3.373) & (3.308) & $(9.960)$ \\
\hline \multirow{2}{*}{$\begin{array}{l}\text { Joint relevance of } \\
\text { instruments }\end{array}$} & 15.578 & 11.350 & 9.35 \\
\hline & {$[0.000]$} & {$[0.000]$} & {$[0.000]$} \\
\hline
\end{tabular}


Table 9 (continued)

\begin{tabular}{llll}
\hline & \multicolumn{2}{l}{ Restricted model } & \multicolumn{2}{l}{ Unrestricted model } \\
\cline { 3 - 4 } & $(1)$ & $(2)$ & $(3)$ \\
\hline $\mathrm{R}^{2}$ & 0.380 & 0.384 & 0.966 \\
Number of Obs & 18,877 & 18,877 & 18,877 \\
\hline
\end{tabular}

\section{Appendix D}

As an additional robustness check, we re-estimate by OLS and 2SLS an extended version of the baseline model of Eq. (3), including as an additional explanatory variable the average educational level in the origin country $i$ at time $t$ (in logarithms) ${ }^{16}$, considering the mean years of schooling of people aged 25 and older (collected from the United Nations Development Program). ${ }^{17}$ Columns 1 and 2 of Table 10 present the OLS estimation results considering, respectively, the specification without and with the interaction term between ODA and governance, while columns 4 and 5 report the 2SLS results for the analogous specifications. Using the 2SLS estimated coefficients, we show in Fig. 5 how asylum seeking respond to changes in the variables of interest, considering different values of ODA and governance. The results confirm the robustness of previous conclusion, since we find that asylum seekers significantly decrease with the governance quality in the origin country, when foreign aid is received. Moreover, the ODA's effect on asylum seekers is also dependent on the governance quality of the origin country. Interestingly, it is also found that the average level of education in the origin country significantly increase asylum seeking, which is consistent with previous literature (e.g., Ivlevs and King 2012; Aksoy and Poutvaara 2021) ${ }^{18}$

Additionally, to evaluate whether the governance quality effect on asylum seeking varies by the education level, we also estimate an alternative version of Eq. (3), which includes as additional regressors the mean educational level in the source country and its interaction with the governance quality (instead of the interaction term between ODA and governance). That is, we consider the following specification:

\footnotetext{
16 Difference between emigration and immigration.

17 According to the data sample, the mean years of schooling of people aged 25 and older in the source countries is 4.653 , the standard deviation is 2.051 , and the minimum and maximum levels are, respectively, 0.9 and 10.2 years.

18 We have also used the (absolute) logarithmic difference between the average educational levels in the source and destination countries instead of considering the average level of education in the origin country (in logarithms). The results, not presented here for brevity, are consistent with our conclusions and are available upon request from the authors. In particular, it is found that asylum seeking significantly decreases with the level of governance quality in the source country, regardless of the educational gap between source and destination countries. Interestingly, it is also found that asylum claims significantly increase in face of reductions in the educational gap between countries.
} 


\section{a. Effects of governance quality and foreign aid on asylum seeking}
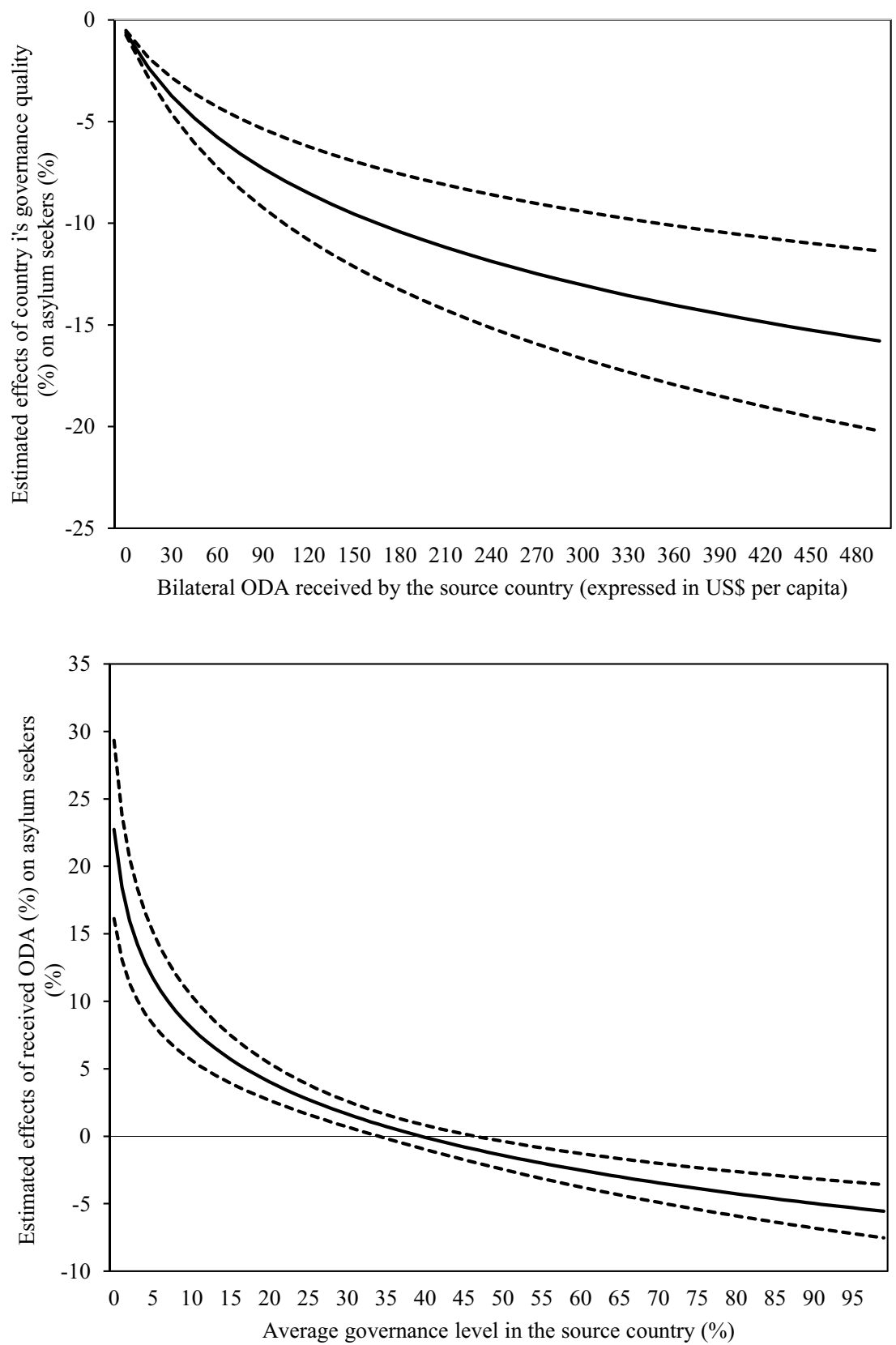

Note: Dashed lines represent the confidence intervals at $90 \%$. Figures are based on the estimated coefficients shown in column (5) of Table D.1.

Fig. 5 Estimated elasticities from the 2SLS regression (log-log specification, adding the mean educational level of origin country as control variable) 
b. Effects of governance quality by educational level of origin country on asylum seeking
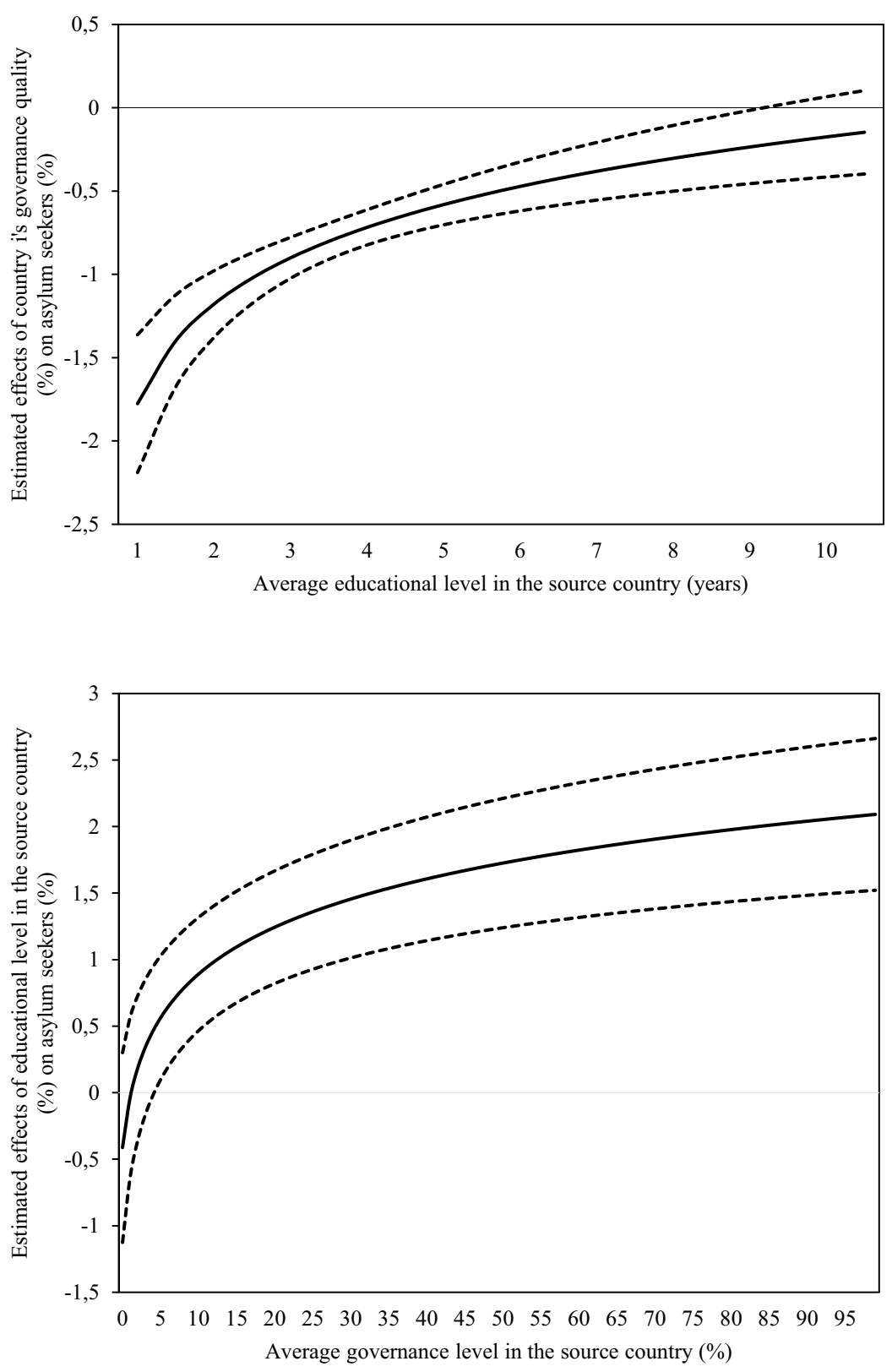

Note: Dashed lines represent the confidence intervals at $90 \%$. Figures are based on the estimated coefficients shown in column (6) of Table D.1. 
Table 10 Effect of governance quality and foreign aid on asylum migration (log-log model, alternative specifications)

\begin{tabular}{|c|c|c|c|c|c|c|}
\hline \multirow[t]{2}{*}{ Dep. variable: $\ln A_{i j t}$} & \multicolumn{3}{|l|}{ FE } & \multicolumn{3}{|l|}{ IV-FE } \\
\hline & (1) & (2) & (3) & (4) & $(5)$ & (6) \\
\hline $\ln G_{i t}$ & $\begin{array}{l}-0.742^{* * * *} \\
(0.062)\end{array}$ & $\begin{array}{l}10.456^{* * * *} \\
(2.002)\end{array}$ & $\begin{array}{l}-1.415^{\text {**** }} \\
(0.153)\end{array}$ & $\begin{array}{l}-0.751^{\text {***** }} \\
(0.064)\end{array}$ & $\begin{array}{l}22.868^{* * * *} \\
(4.215)\end{array}$ & $\begin{array}{l}-1.399^{* * * *} \\
(0.168)\end{array}$ \\
\hline $\ln O D A_{i j t}$ & $\begin{array}{l}0.321 \\
(0.238)\end{array}$ & $\begin{array}{l}10.576^{* * *} \\
(1.945)\end{array}$ & $\begin{array}{l}0.326 \\
(0.237)\end{array}$ & $\begin{array}{l}0.366 \\
(0.491)\end{array}$ & $\begin{array}{l}22.729^{* * * *} \\
(4.015)\end{array}$ & $\begin{array}{l}0.364 \\
(0.489)\end{array}$ \\
\hline $\operatorname{lneduc}_{i t}$ & $\begin{array}{l}0.982^{* * * *} \\
(0.234)\end{array}$ & $\begin{array}{l}0.983^{\text {**** }} \\
(0.232)\end{array}$ & $\begin{array}{l}-0.628 \\
(0.391)\end{array}$ & $\begin{array}{l}1.149^{\text {**** }} \\
(0.256)\end{array}$ & $\begin{array}{l}1.105^{* * * *} \\
(0.254)\end{array}$ & $\begin{array}{l}-0.412 \\
(0.433)\end{array}$ \\
\hline $\ln G_{i t} \cdot \ln O D A_{i j t}$ & & $\begin{array}{l}-2.911^{* * *} \\
(0.521)\end{array}$ & & & $\begin{array}{l}-6.142^{* * *} \\
(1.097)\end{array}$ & \\
\hline $\ln G_{i t} \cdot \ln e d u c_{i t}$ & & & $\begin{array}{l}0.572^{* * *} \\
(0.116)\end{array}$ & & & $\begin{array}{l}0.544^{* * *} \\
(0.127)\end{array}$ \\
\hline $\ln Y_{i t}$ & $\begin{array}{l}-0.309^{* *} \\
(0.141)\end{array}$ & $\begin{array}{l}-0.328^{* * *} \\
(0.139)\end{array}$ & $\begin{array}{l}-0.574^{* * *} \\
(0.152)\end{array}$ & $\begin{array}{l}-0.406^{\text {*** }} \\
(0.152)\end{array}$ & $\begin{array}{l}-0.443^{* * *} \\
(0.151)\end{array}$ & $\begin{array}{l}-0.596^{* * *} \\
(0.162)\end{array}$ \\
\hline lndist $_{i j}$ & $\begin{array}{l}-0.787^{\text {**** }} \\
(0.186)\end{array}$ & $\begin{array}{l}-0.784^{* * *} \\
(0.187)\end{array}$ & $\begin{array}{l}-0.792^{* * * *} \\
(0.185)\end{array}$ & $\begin{array}{l}-0.766^{\text {**** }} \\
(0.182)\end{array}$ & $\begin{array}{l}-0.746^{* * *} \\
(0.182)\end{array}$ & $\begin{array}{l}-0.770^{\text {**** }} \\
(0.181)\end{array}$ \\
\hline colony $_{i j}$ & $\begin{array}{l}0.891^{\text {*** }} \\
(0.168)\end{array}$ & $\begin{array}{l}0.823^{* * *} \\
(0.164)\end{array}$ & $\begin{array}{l}0.889^{* * * *} \\
(0.168)\end{array}$ & $\begin{array}{l}0.871^{\text {**** }} \\
(0.168)\end{array}$ & $\begin{array}{l}0.644^{* * * *} \\
(0.164)\end{array}$ & $\begin{array}{l}0.870^{* * * *} \\
(0.168)\end{array}$ \\
\hline clang $_{i j}$ & $\begin{array}{l}1.060^{* * * *} \\
(0.127)\end{array}$ & $\begin{array}{l}1.048^{\text {**** }} \\
(0.125)\end{array}$ & $\begin{array}{l}1.060^{* * * *} \\
(0.127)\end{array}$ & $\begin{array}{l}1.089^{* * * *} \\
(0.125)\end{array}$ & $\begin{array}{l}1.046^{\text {***** }} \\
(0.121)\end{array}$ & $\begin{array}{l}1.089^{* * * *} \\
(0.125)\end{array}$ \\
\hline $\operatorname{lnfatal}_{i t}$ & $\begin{array}{l}0.029^{\text {**** }} \\
(0.008)\end{array}$ & $\begin{array}{l}0.029^{* * *} \\
(0.008)\end{array}$ & $\begin{array}{l}0.027^{* * *} \\
(0.008)\end{array}$ & $\begin{array}{l}0.025^{* * *} \\
(0.009)\end{array}$ & $\begin{array}{l}0.025^{* * *} \\
(0.009)\end{array}$ & $\begin{array}{l}0.022^{* *} \\
(0.009)\end{array}$ \\
\hline lnypop $_{i t}$ & $\begin{array}{l}-1.480^{\text {**** }} \\
(0.256)\end{array}$ & $\begin{array}{l}-1.435^{* * *} \\
(0.253)\end{array}$ & $\begin{array}{l}-1.346^{* * *} \\
(0.255)\end{array}$ & $\begin{array}{l}-1.842^{\text {**** }} \\
(0.265)\end{array}$ & $\begin{array}{l}-1.734^{* * *} \\
(0.262)\end{array}$ & $\begin{array}{l}-1.702^{\text {*** }} \\
(0.265)\end{array}$ \\
\hline $\operatorname{lnurb}_{i t}$ & $\begin{array}{l}0.665^{*} \\
(0.371)\end{array}$ & $\begin{array}{l}0.564 \\
(0.365)\end{array}$ & $\begin{array}{l}0.526 \\
(0.368)\end{array}$ & $\begin{array}{l}1.210^{\text {**** }} \\
(0.425)\end{array}$ & $\begin{array}{l}0.983^{* *} \\
(0.415)\end{array}$ & $\begin{array}{l}1.068^{* *} \\
(0.423)\end{array}$ \\
\hline lnagric $_{i t}$ & $\begin{array}{l}0.023 \\
(0.079)\end{array}$ & $\begin{array}{l}0.020 \\
(0.078)\end{array}$ & $\begin{array}{l}-0.024 \\
(0.078)\end{array}$ & $\begin{array}{l}-0.074 \\
(0.083)\end{array}$ & $\begin{array}{l}-0.076 \\
(0.083)\end{array}$ & $\begin{array}{l}-0.089 \\
(0.083)\end{array}$ \\
\hline lnemployr $_{i t}$ & $\begin{array}{l}0.633 \\
(0.480)\end{array}$ & $\begin{array}{l}0.551 \\
(0.474)\end{array}$ & $\begin{array}{l}0.309 \\
(0.478)\end{array}$ & $\begin{array}{l}0.354 \\
(0.501)\end{array}$ & $\begin{array}{l}0.241 \\
(0.499)\end{array}$ & $\begin{array}{l}0.034 \\
(0.500)\end{array}$ \\
\hline lntemp $_{i t}$ & $\begin{array}{l}1.261 \\
(1.184)\end{array}$ & $\begin{array}{l}1.304 \\
(1.171)\end{array}$ & $\begin{array}{l}1.731 \\
(1.177)\end{array}$ & $\begin{array}{l}2.895^{* *} \\
(1.278)\end{array}$ & $\begin{array}{l}2.832^{* *} \\
(1.250)\end{array}$ & $\begin{array}{l}3.148^{* *} \\
(1.274)\end{array}$ \\
\hline lnprecip $_{i t}$ & $\begin{array}{l}-0.005 \\
(0.060)\end{array}$ & $\begin{array}{l}0.001 \\
(0.059)\end{array}$ & $\begin{array}{l}-0.010 \\
(0.060)\end{array}$ & $\begin{array}{l}0.008 \\
(0.062)\end{array}$ & $\begin{array}{l}0.022 \\
(0.062)\end{array}$ & $\begin{array}{l}0.005 \\
(0.062)\end{array}$ \\
\hline Hansen $\mathrm{J}$ test & & & & $\begin{array}{l}2.363 \\
{[0.669]}\end{array}$ & $\begin{array}{l}7.363 \\
{[0.392]}\end{array}$ & $\begin{array}{l}2.055 \\
{[0.726]}\end{array}$ \\
\hline Kleibergen-Paap rk LM test & & & & $\begin{array}{l}9.561 \\
{[0.089]}\end{array}$ & $\begin{array}{l}50.517 \\
{[0.000]}\end{array}$ & $\begin{array}{l}9.554 \\
{[0.089]}\end{array}$ \\
\hline Kleibergen-Paap rk Wald F & & & & 15.238 & 10.180 & 15.293 \\
\hline Durbin-Wu-Hausman test & & & & $\begin{array}{l}96.63 \\
{[0.000]}\end{array}$ & $\begin{array}{l}156.50 \\
{[0.000]}\end{array}$ & $\begin{array}{l}84.64 \\
{[0.000]}\end{array}$ \\
\hline $\mathrm{R}^{2}$ & 0.699 & 0.700 & 0.700 & & & \\
\hline AIC & 62,164 & 62,069 & 62,069 & 56,710 & 56,787 & 56,650 \\
\hline
\end{tabular}


Table 10 (continued)

\begin{tabular}{|c|c|c|c|c|c|c|}
\hline \multirow[t]{2}{*}{ Dep. variable: $\ln A_{i j t}$} & \multicolumn{3}{|l|}{ FE } & \multicolumn{3}{|l|}{ IV-FE } \\
\hline & (1) & (2) & (3) & (4) & (5) & (6) \\
\hline Obs. (NxT) & 20,240 & 20,240 & 20,240 & 18,439 & 18,439 & 18,439 \\
\hline
\end{tabular}

All regressions include origin (i) and destination-year (jt) fixed effects. Sampled period ranges from 1996 to 2018. Heteroskedasticity- and autocorrelation-consistent s.e. are presented in parentheses, while p-values are in brackets. We use ***, and $* * *$ to denote statistical significance at the $10 \%, 5 \%$, and $1 \%$ levels, respectively. $\uparrow$ The IV-FE refers to the 2SLS estimator. In columns 4 and 6, the ODA per capita has been instrumented by its own lagged values in levels (up to four years) and a variable based on donorgovernment fractionalization, $\sum \overline{P i j} \cdot$ Fracjtj (Dreher et al., 2019). Additionally, in column 5 analogous instruments are used for the interaction term between ODA and governance

$$
\begin{aligned}
\ln A_{i j t} & =\varphi_{0}+\varphi_{1} \ln G_{i t}+\varphi_{2} \operatorname{lnODA}_{i j t} \varphi_{3} \operatorname{lneduc}_{i t} \\
& +\varphi_{4} \ln G_{i t} \cdot \ln e d u c_{i t}+\alpha_{1} \ln Y_{i t}+\alpha_{2} \text { lndist }_{i j} \\
& +\alpha_{3} \text { colony }_{i j}+\alpha_{4} \text { clang }_{i j}+\beta^{\prime} Z_{i t}+\theta_{i}+\delta_{j t}+u_{i j t}
\end{aligned}
$$

where all variables have already been defined in the text. The corresponding OLS and 2SLS results are presented in column 3 and 5, respectively, of Table 10. The estimated elasticities are reported in Fig. 5, which shows how asylum seeking significantly increase with the education level in the source country, regardless of the level of governance quality. The figure also confirms that poor governance quality in the source country significantly stimulates the asylum claims from Africans in Europe, irrespective of the educational level (ranging from 0.9 to 10.2 years of education in the sample).

Acknowledgements The authors would like to thank participants at the 22nd INFER Annual Conference (Paris, December 2020) and the XVII INTECO Workshop on Economic Integration (Valencia, November 2020) for their helpful comments and suggestions. The authors alone are responsible for the content of this work and any shortcomings which may remain. I. Martinez-Zarzoso is also grateful to the financial support received from Project PID2020-114646RB-C42 (Ministerio de Economía y Competitividad), PROMETEO2018/108 (Generalitat Valenciana) and from project UJI-B2020-57 (Universitat Jaume I).

Funding Open Access funding enabled and organized by Projekt DEAL.

Open Access This article is licensed under a Creative Commons Attribution 4.0 International License, which permits use, sharing, adaptation, distribution and reproduction in any medium or format, as long as you give appropriate credit to the original author(s) and the source, provide a link to the Creative Commons licence, and indicate if changes were made. The images or other third party material in this article are included in the article's Creative Commons licence, unless indicated otherwise in a credit line to the material. If material is not included in the article's Creative Commons licence and your intended use is not permitted by statutory regulation or exceeds the permitted use, you will need to obtain permission directly from the copyright holder. To view a copy of this licence, visit http://creativecommons.org/ licenses/by/4.0/.

\section{References}

Adepoju A (2007) Migration in sub-Saharan Africa. A background paper commissioned by the Nordic Africa Institute for the Swedish Government White Paper on Africa. Human Resources Development Centre, Lagos

Aksoy CG, Poutvaara P (2019) Refugees' and irregular migrants' Self-selection into Europe: Who migrates where? CESifo Working Paper Series 7781 
Aksoy CG, Poutvaara P (2021) Refugees' and irregular migrants' self-selection into Europe. J Dev Econ 152:102681

Anderson J (2011) The Gravity Model. The Annual Review of Economics 3:133-160

Azeng TF, Yogo TU (2013) Youth unemployment and political instability in selected developing countries. Tunis, Tunisia: African Development Bank

Beine M, Bertoli S, Fernández-Huertas Moraga J (2015) A practitioners' guide to gravity models of international migration. The World Economy 39(4):496-512

Belloc F (2015) International Economic Assistance and Migration: The Case of Sub-Saharan Countries. Int Migr 53(1):187-201

Bergstrand JH (1985) The gravity equation in international trade: some micro eco nomic foundations and empirical evidence. Rev Econ Stat 67:474-481

Bermeo SB, Leblang D (2015) Migration and foreign aid. International Organization, pp 627-657

Berthélemy JC, Beuran M, Maurel M (2009) Aid and migration: Substitutes or complements? World Dev 37(10):1589-1599

Bertoli S, Fernández-Huertas Moraga J (2017) Gravity Models in the Migration and Development Nexus. Revue D'économie Du Développement 25(3):69-91

Bodvarsson ÖB, Van den Berg H (2013) The Economics of Immigration: Theory and Policy. Springer Science \& Business Media, New York

Boone P (1996) Politics and the effectiveness of foreign aid. Eur Econ Rev 40(2):289-329

Borjas GJ (1987) Self-Selection and the Earnings of Immigrants. Am Econ Rev 77(4):531-553

Borjas GJ (1989) Economic theory and international migration. Int Migr Rev 23(3):457-485

Borjas GJ (1999) The economic analysis of immigration. Handbook of Labor Economics 3:1697-1760

Castillejo C (2017) The European Union Trust Fund for Africa: What implications for future EU development policy? German Development Institute (DIE) Briefing Paper 5/2017. Bonn, Germany

Center for Systemic Peace (2017) Polity IV Project: Political Regime Characteristics and Transitions, 1800-2013. Available at: http://www.systemicpeace.org/polity/polity4.htm.

Chen N (2004) Intra-national versus international trade in the European Union: Why do national borders matter? J Int Econ 63(1):93-118

Cooray A, Schneider F (2016) Does corruption promote emigration? An empirical examination. J Popul Econ 29(1):293-310

Correia S, Guimarães P, Zylkin T (2020) Fast Poisson estimation with high-dimensional fixed effects. Stand Genomic Sci 20(1):95-115

Cruz C, Keefer P, Scartascini C (2018) Database of Political Institutions 2017 (DPI2017). Inter-American Development Bank. Numbers for Development

Czaika M, Mayer A (2011) Refugee movements and aid responsiveness of bilateral donors. J Dev Stud 47(3):455-474

Davenport C, Moore W, Poe S (2003) Sometimes you just have to leave: Domestic threats and forced migration, 1964-1989. International Interactions 29(1):27-55

Dimant E, Krieger T, Meierrieks D (2013) The effect of corruption on migration, 1985-2000. Appl Econ Lett 20(13):1270-1274

Docquier F, Lohest O, Marfouk A (2007) Brain drain in developing countries. World Bank Economic Review 21(2):193-218

Dreher A, Fuchs A, Langlotz S (2019) The effects of foreign aid on refugee flows. Eur Econ Rev 112:127-147

Dreher A, Krieger T, Meierrieks D (2011) Hit and (they will) run: The impact of terrorism on migration. Econ Lett 113(1):42-46

Feenstra RC (2016) Advanced international trade: Theory and evidence, 2nd edn. Princeton University Press, Princeton, NJ

Gamso J, Yuldashev F (2018) Does rural development aid reduce international migration? World Dev 110:268-282

Giménez-Gómez JM, Walle YM, Zergawu YZ (2019) Trends in African migration to Europe: Drivers beyond economic motivations. J Conflict Resolut 63(8):1797-1831

Greene WH (2003) Econometric analysis. Pearson Education, New Jersey

Hatton T (2016) The migration crisis and refugee policy in Europe. Refugees and Economic Migrants $15: 15-27$

Hatton T, Moloney J (2015) Applications for asylum in the developed world: Modelling asylum claims by origin and destination. A LONG WAY TO GO 227 
Hatton TJ, Williamson JG (2005) What fundamentals drive world migration?. In Poverty, international migration and asylum. Palgrave Macmillan, London, pp 15-38

Hatton TJ, Williamson JG (2011) Are third world emigration forces abating? World Dev 39(1):20-32

Head K, Mayer T (2014) Gravity Equations: Workhorse, Toolkit, Cookbook. In: Gopinath G, Helpman E, Rogoff K (eds) Handbook of International Economics, 4. North Holland, pp 131-195

Ivḷevs A, King RM (2012) Does more schooling make you run for the border? Evidence from postindependence Kosovo. J Dev Stud 48(8):1108-1120

Kang YD (2021) Refugee crisis in Europe: determinants of asylum seeking in European countries from 2008-2014. J Eur Integr 43(1):33-48

Karemera D, Oguledo VI, Davis B (2000) A gravity model analysis of international migration to North America. Appl Econ 32(13):1745-1755

Karras G, Chiswick CU (1999) Macroeconomic determinants of migration: The case of Germany 19641988. Int Migr 37(4):657-677

Kaufmann D, Kraay A, Mastruzzi M (2016) Worldwide governance indicators (WGI). The World Bank Group, Washington D.C

Kleibergen F, Paap R (2006) Generalized reduced rank tests using the singular value decomposition. Journal of Econometrics 133(1):97-126

Kosack S (2003) Effective aid: How democracy allows development aid to improve the quality of life. World Dev 31(1):1-22

Lahiri S, Raimondos-Møller P (2000) Lobbying by ethnic groups and aid allocation. Econ J 110(462):62-79

Lanati M, Thiele R (2018) The impact of foreign aid on migration revisited. World Dev 111:59-74

Lee ES (1966) A theory of migration. Demography 3(1):47-57

Lewbel A (1997) Constructing instruments for regressions with measurement error when no additional data are available, with an application to patents and R\&D. Econometrica 65(5):1201-1213

Lucas RE (2006) Migration and economic development in Africa: A review of evidence. J Afr Econ 15(2):337-395

Marchiori L, Maystadt JF, Schumacher I (2012) The impact of weather anomalies on migration in subSaharan Africa. J Environ Econ Manag 63(3):355-374

Martin PL (1993) Trade and migration: NAFTA and agriculture. Institute for International Economics

Martin PL, Taylor JE (1996) The anatomy of a migration hump. Development Strategy, Employment, and Migration: Insights from Models. Paris: Organization for Economic Cooperation and Development, pp 43-62

Mayda AM (2010) International migration: a panel data analysis of the determinants of bilateral flows. J Popul Econ 23:1249-1274

Melander E, Öberg M (2006) Time to go? Duration dependence in forced migration. International Interactions 32(2):129-152

Moore WH, Shellman SM (2004) Fear of persecution: Forced migration, 1952-1995. J Conflict Resolut 48(5):723-745

Murat M (2020) Foreign aid, bilateral asylum immigration and development. J Popul Econ 33(1):79-114

Naudé W (2010) The determinants of migration from Sub-Saharan African countries. J Afr Econ $19(3): 330-356$

Neumayer E (2005) Bogus refugees? The determinants of asylum migration to Western Europe. Int Stud Quart 49(3):389-409

Ortega F, Peri G (2013) The effect of income and immigration policies on international migration. Migration Studies 1:47-74

Poprawe M (2015) On the relationship between corruption and migration: empirical evidence from a gravity model of migration. Public Choice 163(3-4):337-354

Raleigh C (2011) The search for safety: The effects of conflict, poverty and ecological influences on migration in the developing world. Glob Environ Chang 21:S82-S93

Ravenstein EG (1889) The laws of migration. J Roy Stat Soc 52(2):241-305

Rayp G, Ruyssen I (2010) Africa on the move: an extended gravity model of intra-regional migration. APPAM, Maastricht, Netherlands

Reed WR (2015) On the practice of lagging variables to avoid simultaneity. Oxford Bull Econ Stat 77(6):897-905

Roy AD (1951) Some thoughts on the distribution of earnings. Oxf Econ Pap 3(2):135-146

Santos Silva JMC, Tenreyro S (2006) The log of the gravity. Rev Econ Stat 88(4):641-658 
Schmeidl S (1997) Exploring the causes of forced migration: A pooled time-series analysis, 1971-1990. Social Science Quarterly, pp 284-308

Stock JH, Yogo M (2005) Testing for weak instruments in linear IV regression. Identification and Inference for Econometric Models: Essays in Honor of Thomas Rothenberg 80(4):2

Thielemann E (2004) Why asylum policy harmonisation undermines refugee burden-sharing. European Journal of Migration and Law 6(1):47-65

Wooldridge JM (2010) Econometric analysis of cross section and panel data. MIT Press, Cambridge, Massachusetts

Wooldridge JM (2015) Control function methods in applied econometrics. J Hum Resour 50(2):420-445

Yotov YV, Piermartini R, Monteiro JA, Larch M (2016) An advanced guide to trade policy analysis: The structural gravity model. World Trade Organization, Geneva

Ziesemer TH (2011) Developing countries' net-migration: The impact of economic opportunities, disasters, conflicts, and political instability. Int Econ J 25(3):373-438

Publisher's Note Springer Nature remains neutral with regard to jurisdictional claims in published maps and institutional affiliations. 